UNIVERSIDADE DE BRASÍLIA

DEPARTAMENTO DE SERVIÇO SOCIAL

O TRABALHO DOS PRESOS DO REGIME SEMI-ABERTO, EM EMPRESAS PRIVADAS DO DISTRITO FEDERAL

Fabiana Jardim Sena

Brasília, junho de 2007 
Fabiana Jardim Sena

\title{
O TRABALHO DOS PRESOS EM REGIME SEMI-ABERTO, EM EMPRESAS PRIVADAS DO DISTRITO FEDERAL
}

\begin{abstract}
Monografia apresentada como exigência parcial para a obtenção do título de graduação em Serviço Social, pela Universidade de Brasília, sob a orientação do professor Doutor Mário Ângelo Silva.
\end{abstract}

Brasília, junho de 2007 
A todos aqueles que acreditam que as mudanças ainda são possíveis e que as barreiras e dificuldades da vida podem servir como degraus para o crescimento. 


\section{Resumo}

Atualmente, o trabalho é o centro das relações sociais, econômicas e políticas que vivenciamos. A partir dele é que as classes sociais são definidas, as categorias consolidadas e os direitos exigidos. Essa importância do trabalho atinge a sociedade como um todo, inclusive os indivíduos que cumprem pena privativa de liberdade. Embora este trabalho seja considerado como benefício para os atores envolvidos e para a legislação vigente, compreendemos que o trabalho é antes de qualquer coisa, um direito social.

Na execução penal brasileira, os presos possuem autorização para trabalhar externamente quando cumprem pena no regime semi-aberto, benefício conhecido como Trabalho Externo. As atividades laborais destes indivíduos são originalmente desenvolvidas em órgãos públicos, mas diante da escassez de vagas, o Trabalho Externo em Empresas Privadas foi instituído como estratégia do egresso se inserir no mercado de trabalho, desde o ano de 2000.

Os empresários que oportunizam vagas para sentenciados são motivados, em sua grande maioria, por laços afetivos com o trabalhador preso ou com sua família. Não possuem incentivos fiscais ou sociais para desenvolver essa iniciativa e também não são acompanhados por profissionais responsáveis.

A legislação que regulamenta o benefício, cita a diminuição do salário mínimo do sentenciado (1/4 de salário mínimo) e a perda de direitos trabalhistas (férias, $13^{\circ}$ salário, FGTS, carteira assinada, dentre outros) como incentivos à participação social na reinserção no mercado de trabalho dos internos.

Em contrapartida, temos um quadro de sentenciados composto por pessoas de baixa qualificação profissional, poucos anos de estudo e que ainda carregam o estigma dos anos de encarceramento. A junção desses três pilares forma a atual situação do trabalho dos sentenciados em empresas privadas do Distrito Federal, tema desta pesquisa.

No primeiro semestre de 2007, período em que a pesquisa foi realizada, o universo de sentenciados na condição do regime semi-aberto era composto por 440 internos, que trabalham em empresas de variados ramos no Distrito Federal. 
Através de entrevistas semi-estruturas, realizadas com os três atores envolvidos na temática: sentenciados, empresários e profissionais, buscamos analisar as peculiaridades das atividades desenvolvidas, como faixa salarial dos sentenciados, as funções dentro da empresa, relação interpessoal com colegas e chefes e as condições em que este trabalho é realizado.

Após a análise bibliográfica sobre a temática, a visita às empresas e as entrevistas, pudemos concluir que o trabalho dos sentenciados não é um trabalho escravo, permeado de sanções e humilhações físicas como ocorria nos séculos passados.

Mas essa mão de obra também não deixa de ser explorada, como vem ocorrendo com maioria da mão de obra dos brasileiros. Seus direitos estão sendo diminuídos em nome do incentivo à participação das empresas privadas no processo de reinserção social, suas atividades não são acompanhadas e o Estado vem se desresponsabilizando cada vez mais do seu papel central.

Palavras-chave: Sentenciado em regime semi-aberto, Trabalho, Empresas Privadas e Direito. 


\section{Agradecimentos}

Agradeço a Deus, pela oportunidade de conhecer uma realidade tão complexa como é a questão penitenciária no Brasil e vivenciar que independente da situação, o ser humano sempre precisa de perdão, amor e mudança de vida, que somente Ele pode proporcionar; Agradeço aos meus pais, por todos os anos de apoio incondicional;

À minha segunda mãe, Luzia, por todo carinho e cuidado em momentos tão importantes; Aos meus eternos amigos da Igreja de Cristo em Brasília, testemunhas da minha história. Vocês são mais do que meros colegas são irmãos para a vida toda! Especialmente à Juliana e à Islaine, por todos os anos de amizade.

Aos novos amigos que são igualmente fundamentais. Por demonstrarem que a vida sempre reserva excelentes surpresas: Priscilla, Tiago, Gustavo, Adriana e Penina. Ao Jony, por ser a personificação da palavra companheiro.

Especialmente à professora Maria Auxiliadora César, pela valiosa orientação no projeto nesta pesquisa, ao professor Mário Ângelo pelas orientações neste trabalho e aos demais professores do Departamento de Serviço Social da Universidade de Brasília pelo conhecimento ministrado.

A todos aqueles que contribuíram durante anos para que eu alcançasse essa vitória, muito obrigada! 


\section{Sumário}

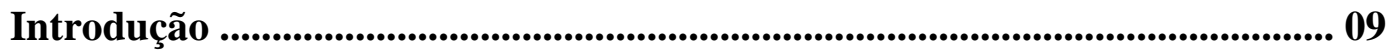

Objetivo Geral e Específicos .................................................................... 10

Metodologia ...................................................................................................................... 11

Capítulo 1 - Breve Histórico Sobre as Prisões ................................................ 13

1.1 Modelo de Aurbun ...................................................................................... 15

1.2 Modelo da Filadélfia ................................................................................. 17

$1.3 \mathrm{O}$ fracasso do sistema prisional ........................................................... 19

Capítulo 2 - A construção histórica do Direito ................................................. 22

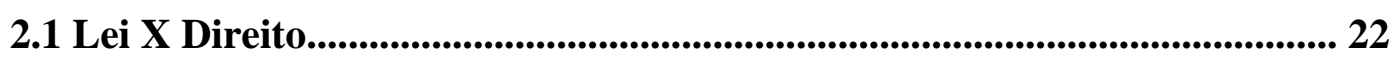

2.2 Direito Civil, Político e Social do preso .................................................... 24

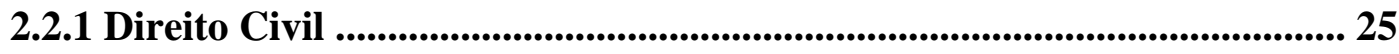

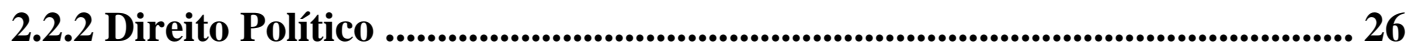

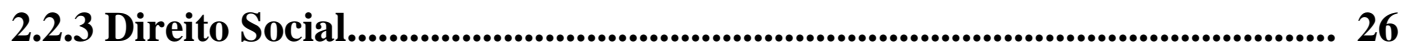

2.2.4 Direito X Desreponsabilização do Estado ................................................ 28

Capítulo 3 - Trabalho ........................................................................................ 30

3.1 As metamorfoses do mundo do trabalho ............................................... 30

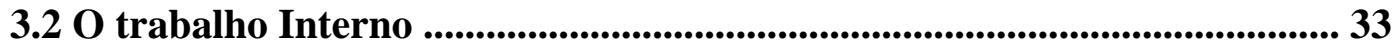

3.30 Trabalho Externo ..................................................................................... 34

3.3.1 O modelo de progressão inglês. ….................................................................. 34

3.3.2 O modelo de progressão irlandês .............................................................. 35

3.3.3 O modelo de progressão brasileiro ....................................................... 35

3.4 Trabalho Penal: Parte da Pena ou Benefício? ......................................... 35

Capítulo 4 - Análise dos dados da pesquisa ..................................................... 39

3.1 O surgimento do trabalho dos presos em empresas privadas ..................... 39

3.2 Os profissionais que lidam com a concessão do benefício ......................... 40

$3.3 \mathrm{O}$ perfil das empresas.............................................................................. 42 
5. Análise das entrevistas ..................................................................................... 50

5.1 Entrevista com os sentenciados ............................................................. 51

5.2 Entrevista com os empregadores ................................................................. 54

5.3 Entrevista com os profissionais................................................................ 57

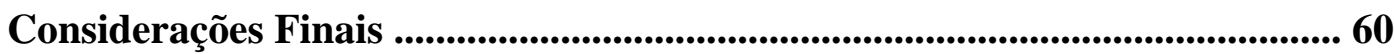

Referências Bibliográficas

Anexos 


\section{Introdução}

Para melhor compreendermos o Trabalho Externo dos sentenciados em regime semi-aberto em empresas privadas do Distrito Federal, como ele vem se consolidando, suas características e como ele está colaborando para a reinserção social dessa população, precisamos considerar que estas atividades são apenas parte de uma conjuntura muito maior, no contexto da Lei de Execução Penal e do sistema penitenciário brasileiro.

No capítulo 1 traçamos um Breve Histórico sobre as Prisões e como o trabalho prisional surgiu dentro desta instituição. A função punitiva dos estabelecimentos prisionais está historicamente associada às formas de trabalho forçado. Refletimos como o Trabalho Externo, na modalidade de benefício, se situa dentro da construção da execução penal, na perspectiva dos direitos, e como se dá a exploração da força de trabalho das pessoas apenadas.

Sabemos que toda esta discussão é permeada pelo direito do sentenciado a trabalhar. O capítulo 2 abordará como esses direitos vem sendo garantidos e efetivados, a participação dos movimentos sociais na luta pela igualdade de oportunidade e como a parceria entre sociedade civil e Estado, típica do neoliberalismo, vem atingindo o Trabalho Externo em empresas privadas

Como o objetivo do Trabalho Externo é inserir o preso trabalhador no mercado de trabalho, não podemos deixar de analisar a atual configuração sob a ótica das metamorfoses do mundo do trabalho, oriundas do modo de produção capitalista e da teoria econômica neoliberal, que serão analisados no Capítulo 3.

Mas quando surgiu este benefício? Quais são as empresas que empregam os sentenciados? Qual a motivação destes empresários? Quais são os profissionais envolvidos neste benefício? Estas e outras perguntas específicas serão tratadas no Capítulo 4 desta pesquisa. Utilizaremos dados obtidos na Seção Psicossocial da Vara de Execuções Criminais com os quais elaboramos tabelas originais que traçaram o perfil dos empregadores, principais funções dos sentenciados e vínculos existentes entre empregador e sentenciado.

O capítulo 5 traz a análise das entrevistas realizadas com empregadores, sentenciados e profissionais que lidam com a concessão do benefício do Trabalho Externo. O que auxilia na compreensão de como ele está sendo implementado no 
contexto da execução penal e no cotidiano desses indivíduos que cumprem pena em regime semi-aberto, encarcerados em presídios masculinos do Distrito Federal.

Na Conclusão, buscamos resgatar os principais tópicos abordados durante esta pesquisa e com base nas informações, sugerir algumas proposições que podem melhorar a aplicação do benefício do Trabalho Externo em empresas privadas do Distrito Federal.

\section{Objetivo Geral}

Analisar as percepções sobre o trabalho externo do sentenciado em regime semi-aberto, em empresas privadas do Distrito Federal, do discurso de profissionais operadores do direito, e de empresários participantes dessa medida, tomando como referencial os conceitos de metamorfoses do mundo do trabalho.

\section{Objetivos Específicos}

1. Verificar a faixa salarial dos sentenciados e dos demais funcionários que desenvolvem as mesmas atividades;

2. Mapear o ramo empresarial das instituições que disponibilizam tais vagas;

3. Relacionar os motivos que levaram os empregadores a ofertar o emprego;

4. Detectar os incentivos empresariais existentes ao oferecer uma vaga para o preso egresso;

5. Analisar a bibliografia referente às metamorfoses do trabalho

6. Analisar o discurso e a prática dos profissionais que lidam com a concessão do benefício.

7. Analisar o conceito de direito utilizado pelos profissionais que lidam com a temática, pelos empregadores e pelos sentenciados.

8. Propor sugestões para melhorar o Benefício do Trabalho Externo no Distrito Federal. 


\section{Metodologia}

A pesquisa utilizou pressupostos teóricos e metodológicos da pesquisa social quali-quantitativa, a partir da análise histórico-estrutural. Os dados coletados e analisados referem-se a:

a) Dados secundários referentes aos anos de 2005 e 2006, que proporcionaram traçar o perfil do ramo das empresas, o tipo de atividade, a faixa salarial e o horário de trabalho. Obtidos pela leitura e análise do conteúdo das cópias dos relatórios sociais, que foram encaminhados ao Juiz da Vara, pela SEVEC, no período do $1^{\circ}$ semestre de 2007.

b) Dados primários obtidos através de entrevistas com empregadores, sentenciados e profissionais, com a finalidade de compreender as subjetividades do benefício de Trabalho Externo e como ele se configura dentro da atual estrutura de mercado de trabalho.

c) Participação nas reuniões com os empregadores que ocorreram na SEVEC semanalmente e Participação em Seminários, Simpósios e Palestras cujos objetivos foram promover a discussão sobre a questão dos Direitos Humanos nos Presídios, Educação Prisional, Trabalho no Mundo Atual.

d) Revisão bibliográfica e documental sobre o tema.

No decorrer da pesquisa foram adotados os princípios e pressupostos da dialética marxista, que insere o homem como o agente construtor e transformador da sua história e da realidade, concebida como uma totalidade complexa.

Assim, no processo de construção deste estudo adotamos uma abordagem crítica da realidade. Para tal, foram estabelecidas relações entre teoria e prática empírica, numa abordagem relacional, sendo o trabalho, a categoria fundante, na perspectiva das políticas penitenciárias e dos direitos sociais na sociedade brasileira.

\section{Procedimentos Metodológicos}

Decidimos adotar as seguintes etapas e estratégias: 
- Realizar entrevista com quatro sentenciados que já estão desenvolvendo suas atividades em empresas privadas no Distrito Federal e seus respectivos empregadores, após parecer favorável da Seção Psicossocial da Vara de Execuções Criminais no ano de 2006.

- Embora a pesquisa não possua uma preocupação estatística, foram escolhidos quatro sentenciados que desenvolvem suas atividades em áreas variadas, pois se procura desta forma, estabelecer contrapontos entre as falas dos entrevistados.

- A entrevista está estruturada em duas partes: a primeira, de caráter mais objetivo e perguntas fechadas, pretende conhecer a função ou cargo desempenhado, a carga horária e a remuneração. A segunda parte, com caráter mais subjetivo, reúne entrevistas semi-estruturadas visando compreender a importância do trabalho para o sentenciado, para sua família e suas conseqüências para sua reinserção social.

- Analisar de forma crítica, o aumento da demanda de empresas privadas pelo trabalho externo do sentenciado e relacionar esses dados com as metamorfoses no mundo do trabalho, na era capitalista.

- Entrevistar os profissionais que trabalham diretamente com a concessão dos benefícios do trabalho externo, primordialmente os Assistentes Sociais.

- Conhecer as percepções sobre o trabalho externo entre os profissionais da Seção Psicossocial da Vara de Execuções Criminais (TJDF), que são responsáveis pela triagem documental das empresas e pelo esclarecimento das regras da atividade. 


\section{Breve Histórico das Prisões}

A vida em sociedade exige limites para que todos possam conviver pacificamente. Quando os interesses de alguns se sobrepõem aos de outros, surgem os conflitos. Para nortear a convivência foram criadas leis que estabelecem o padrão correto, as variações de conduta e as penalidades para aqueles que não as cumprem.

Nem todo desvio de conduta é considerado crime; por isso, as conseqüências de certas atitudes podem variar de acordo com a cultura, as leis e o momento histórico vivido por uma sociedade. Com o passar do tempo, os conceitos sobre um determinado comportamento podem mudar, como é o caso da adequação que o Código Penal brasileiro fez quanto aos crimes cometidos na internet, necessidade inexistente até poucos anos.

Segundo Beccaria (2002), o indivíduo abre mão de parte da sua liberdade e a passa para o Estado, constituindo-o depositário de pequenas parcelas das liberdades de cada um. Da união, nasce o fundamento do direito de punir, pois o Estado se torna responsável por manter a ordem por meio de leis que regem o comportamento e visam à harmonia social e de fiscalizar o cumprimento das mesmas.

O crime pode ser punido com advertência, multa, prestação de serviço à comunidade ou recolhimento prisional, última instância de punição, que é aplicada de acordo com a gravidade do delito cometido, os meios empregados (como uso de arma de fogo ou grave ameaça à vítima) e as conseqüências do ato.

As primeiras Casas de Detenção datam do final do século XVII e o início do XVIII, período em que os presos eram mantidos sob total promiscuidade, em locais insalubres, sem higiene, com alimentação irrisória, realizando trabalhosos penosos e sofrendo castigos corporais (MUAKAD, 1998).

As prisões não tinham o mesmo papel que desempenham atualmente na sociedade. Eram locais de encarceramento para pessoas que aguardavam julgamento ou para devedores, até que saldassem suas dívidas. As punições existiam na forma de sanções físicas, que eram momentos de espetáculo, onde os corpos dos presos eram expostos a todo tipo de atrocidade, demonstrando todo o poder do Estado e como os indivíduos encontravam-se indefesos diante das regras sociais. 
"Sem dúvida para nossos olhos atuais a proporção de veredictos de morte, na penalidade da era clássica, pode parecer considerável: as decisões do Châtelet durante o período de 1755 a 1785 comportam 9 a 10\% de penas capitais - roda, forca ou fogueira; em 260 sentenças o Parlamento de Flandres pronunciou 39 condenações à morte, de 1721 a 1730 (e 26 e, 500 entre 1781 e 1790)” . (FOUCAULT, 1987, p. 30)

Embora a quantidade de condenações à morte fosse pouca, os tipos de suplício eram variados: tempo de agonia e exposição pública da pessoa em rodas e fogueira, coleira de ferro, marcação de ferrete, mutilações de partes do corpo como orelha e mão, golpes de açoite, lábios ou língua furados, cadáveres queimados, cinzas jogadas ao vento e corpos arrastados e jogados na rua.

Todas as dores e humilhações eram detalhadamente calculadas, para demonstrar a gravidade do crime, a posição que o criminoso e a vítima tinham na sociedade e, principalmente, a fragilidade dos presos diante da ausência de leis que os protegessem.

Com o passar dos anos e como reflexo das alterações da sociedade, as sanções físicas foram cedendo espaço para o modelo de prisão que temos hoje. Considerando que todos os indivíduos estão ligados por um contrato de direitos e deveres que tem como seu pilar a liberdade, os infratores das regras não erraram somente com a vítima do seu crime, mas sim, com a sociedade como um todo. (FOUCAULT, 1987).

A grande questão que permeia a punição física dos sentenciados é que, na realidade, até esse momento histórico não existe punição, mas, eliminações daqueles que por algum motivo se desviam dos padrões estabelecidos como o correto pela sociedade.

Com a mudança das concepções sobre crime e criminoso, as prisões passam de meras depositárias de seres humanos para assumirem o papel principal na permanência daqueles que necessitam se afastar da sociedade para mudarem o seu comportamento e as suas práticas. Tal mudança tem como eixo norteador a desigualdade entre os indivíduos, resultante da exploração individual e coletiva existente em nossa sociedade expressa nas áreas econômica, social e também penal.

A palavra penitência tão amplamente utilizada pela Igreja Católica tem o significado de "volta sobre si mesmo", o que evidencia que a prisão deveria ser um momento de recolhimento para análise, reflexão e arrependimento (MUAKAD,1998).

Segundo Foucault (1987), a prisão é mais que a substituição da sanção física 
pelo encarceramento, é uma empresa de modificação de indivíduos, mudanças de valores, cultura e padrões econômicos que se utilizam da exaustiva disciplina para moldar o preso de acordo com os interesses do Estado e das classes dominantes.

O grande agente dessas modificações é o isolamento, tratado por Muakad (1998) como o primeiro passo para a loucura. O distanciamento do mundo exterior, o afastamento dos familiares, a falta de contato com os reais motivos que levaram a prática do delito e o distanciamento dos demais colegas de prisão, já que na maioria das vezes a comunicação é proibida, torna o encarceramento cruel e traz conseqüências psíquicas para o sujeito.

A reflexão e o auto conhecimento pregados pela Igreja Católica encontram neste contexto um meio privilegiado para ser alcançado, porque o isolamento e a solidão levam o condenado a acreditar que ele sempre vai ser culpado pelo crime que cometeu, mas nem sempre proporciona um espaço para ponderação da mudança.

Todas as prisões têm o mesmo objetivo. Os meios para alcançá-lo podem ser diferentes de acordo com o modelo adotado pela diretoria do estabelecimento. Diante desta lógica, vamos destacar duas formas distintas de tratamento penal, ambas de origem norte-americana que ainda hoje influenciam na atual estruturação do sistema prisional brasileiro.

\subsection{Modelo de Aurbun}

A maneira de comunicar entre os presos e os guardas dava-se no sentido vertical, a comunicação horizontal era proibida. Um dos motivos era para evitar que os presos se unissem como categorias contra a exploração e as humilhações a que eram submetidos e consequentemente, pensassem em formas de lutar contra o sistema vigente.

Só era permitido falar com os guardas, e mesmo assim com a permissão deles, de forma rápida e baixa. As celas eram individuais, as refeições e o trabalho, coletivo. Obrigá-los a adquirir novos e bons hábitos através da vigilância ativa e do silêncio era o papel da prisão. (FOUCAULT, 1987).

Assim como nesta teoria, o intuito de proporcionar a cada preso um espaço próprio e com privacidade nas prisões modernas, não tem ligação com a idéia de preservação dos direitos humanos. Quando existem celas individuais elas servem para dificultar a comunicação e a possibilidade de formarem rebeliões ou maquinarem formas de fugas, como ocorrem nos presídios de segurança máxima, recentemente adotados no 
país.

Ao contrário do que o Modelo de Aurbun cita, os presídios brasileiros adotaram as celas para muitas pessoas, sem qualquer diferenciação entre o delito cometido, idade ou anos de condenação.

As condições físicas dos presididos brasileiros são precárias, expressão disso é a superlotação das celas. Contamos com presídios melhor estruturados em Brasília, mas mesmo assim, o Centro de Detenção Provisória registrava uma média de 75 presos por cela em dezembro de 2006. (TJDF, 2006)

Abaixo faremos um comparativo entre a quantidade de presos no sistema penitenciário do Distrito Federal e a quantidade de vagas existentes:

Quadro 1: Quantidade de presos/ internados - Dezembro de 2006, Distrito Federal

\begin{tabular}{|l|l|l|l|}
\hline Sistema Penitenciário & Sexo Masculino & Sexo Feminino & Total \\
\hline Presos Provisórios & 1174 & 119 & 1293 \\
\hline Regime Fechado & 2541 & 94 & 2635 \\
\hline Regime Semi -Aberto & 3077 & 101 & 3178 \\
\hline Regime Aberto & 99 & 0 & 99 \\
\hline Medida de Segurança - Internação & 58 & 4 & 62 \\
\hline Medida de Segurança - Ambulatorial & 0 & 0 & 0 \\
\hline Total & 6949 & 318 & 7267 \\
\hline
\end{tabular}

Infopen, 2006

Quadro 2: Número de Vagas - Dezembro de 2006, Distrito Federal

\begin{tabular}{|l|l|l|l|}
\hline Sistema Penitenciário & Sexo Masculino & Sexo Feminino & Total \\
\hline Presos Provisórios & 865 & 119 & 984 \\
\hline Regime Fechado & 3048 & 94 & 3142 \\
\hline Regime Semi- Aberto & 774 & 101 & 875 \\
\hline Regime Aberto & 0 & 0 & 0 \\
\hline Medida de Segurança - Internação & 58 & 4 & 62 \\
\hline Total & 4745 & 318 & 5063 \\
\hline
\end{tabular}

Infopen, 2006

O Distrito Federal apresenta um déficit de 31\% de vagas, quadro otimista 
diante da realidade dos demais estados brasileiros onde o déficit é bem maior. A superlotação prejudica o cumprimento da pena e desrespeita o preso como um ser humano e detentor de direitos.

O quadro demonstra que não existem vagas no regime aberto porque a pena é cumprida em casa. O sentenciado possui autorização para trabalhar e estudar durante o dia e, após as 22 horas, é obrigatório o pernoite na própria residência do sentenciado. A cada dois meses os presos têm que se apresentar à justiça e relatar as atividades laborais que estão executando. Frequentemente, policiais civis realizam visitas nas casas dos sentenciados para averiguar se os mesmos estão cumprindo os horários e as regras do benefício com êxito.

No modelo de Aurbun, as atividades penosas que eram realizadas coletivamente tinham a finalidade de ocupar a ociosidade da privação de liberdade e fazer do preso uma mão de obra produtiva. Este tipo de atividade é a mais fácil de ser implementada dentro de uma prisão, porque a quantidade de recursos necessários é irrisória e o número de profissionais qualificados para o acompanhamento das atividades, também é baixo. Às vezes, uma simples enxada torna o espaço do estabelecimento prisional em um campo de atividades escravas. ${ }^{1}$

\subsection{Modelo da Filadélfia}

Este modelo sofreu forte influência do catolicismo, pois foi o primeiro a trazer a idéia da prisão com um encontro com si mesmo, com a sua consciência. Através do auto conhecimento o sujeito teria a oportunidade de sofrer as mudanças necessárias para retornar ao convívio social.

Contrapondo-se a idéia do Modelo de Aurbun, onde a disciplina e a vigilância são os pilares para a regeneração do indivíduo, no Modelo da Filadélfia todas as mudanças devem ocorrer primeiramente na moral, no campo das idéias, para depois serem expressas nas atitudes. (FOUCAULT, 1987). A explicação da reincidência criminal é que o indivíduo não sofreu mudanças estruturais ou mentais, somente momentâneas diante da repressão que era submetido.

\footnotetext{
${ }^{1} \mathrm{O}$ termo escravo foi utilizado porque o trabalho não possui remuneração e muitas vezes nem a possibilidade de ser aceito ou não. Torna-se uma obrigação, sem direitos, e ainda sob ofensas verbais e castigos corporais, situação similar a que ocorreu com os negros escravos no século XVIII. O incentivo que os presos recebem para trabalhar internamente nos presídios é que a cada 3 dias de trabalho, 1 dia da pena é reduzido. Em poucos casos existe remuneração, como explicaremos de forma mais clara no capítulo sobre Trabalho.
} 
Outro diferencial é que o papel dos guardas e vigilantes é substituído pela arquitetura, já que a estrutura física formal desencadeia a função de coerção. As celas configuram-se de maneira fechada, com pouca iluminação e com baixas condições de higiene.

Por isso, aqueles que não estivessem em contato com a sua consciência renovada, a veriam como uma tumba, mas para os que já estavam em processo de iluminação (ou adequação às regras impostas), era mais uma oportunidade para se aproximarem de Deus. (Idem, Ibidem).

Esta teoria deixou como herança para o modelo de prisão brasileira, a justificativa de que a fé possui forte influência na mudança das práticas delituosas do preso. O problema não está na religião, mas em como o Estado e as autoridades se utilizam dela, para justificar a não implementação de políticas básicas à população carcerária.

Tomemos como exemplo um preso que está sofrendo de uma grave enfermidade. Para algumas autoridades, é melhor que o indivíduo e seus familiares acreditem que a fé pode curá-lo ao invés de assegurar um atendimento médico de qualidade.

As religiões cristãs possuem uma ideologia de mudança de comportamento e caráter através da regeneração do indivíduo pela fé, pela prática de orações e pela leitura da Bíblia Sagrada. Esses hábitos são compatíveis aos ideários do sistema prisional que buscam a mudança do comportamento delituoso através de programas e atividades específicas.

Por esta razão, o espaço das Igrejas tem crescido nas prisões. Esse espaço de ampliação, às vezes é antagônico e contraditório ao direito de assistência religiosa, garantido na Lei de Execução Penal. Porque se configura apenas como um espaço de desresponsabilização do Estado de suas obrigações e deveres.

Quanto à questão do trabalho, neste modelo ele é visto como um consolo e não como uma obrigação, muito parecido com a idéia que hoje existe do trabalho dos sentenciados no regime semi-aberto, pois eles têm a autorização para trabalhar, mas quando não conseguem se inserir no mercado de trabalho, não são penalizados ou obrigados à determinada atividade.

Quando o trabalho é colocado como um consolo é necessário que ele tenha ao menos uma remuneração compatível com o mercado que existe fora do sistema carcerário, o que não ocorre, como veremos nos próximos capítulos. Logo, o “consolo” 
acaba sendo uma punição dobrada, porque o preso não possui meios de sustento pessoal e familiar e nem meio de procurar livremente outras vagas de trabalho.

\subsection{O fracasso do sistema prisional}

Atualmente existe uma grande discussão em torno da eficiência e da eficácia do sistema prisional. Se os sentenciados que ficam anos e anos recolhidos nos presídios brasileiros saem reabilitados para a vida em sociedade, e se, o tempo de privação de liberdade foi suficiente para a mudança de comportamento.

A idéia que está sendo amplamente divulgada nos meios de comunicação é que quando os presos terminam de cumprir as suas penas, estão mais revoltados e mais aptos para o crime do que quando ingressaram no sistema. E de acordo com os índices de reincidência e o aumento das taxas de criminalidade e violência na sociedade, podemos afirmar que tal afirmativa é verdadeira. ${ }^{2}$

A reforma das prisões, tão amplamente discutida entre juristas, psicólogos, assistentes sociais e a sociedade como um todo, não é um tema recente. Hoje esse debate é encarado como conseqüência do processo de industrialização e globalização, mas a reforma prisional é objeto de debate desde o fundamento da prisão como instituição de coerção.

Em 1818 já existiam projetos para a melhoria das prisões através da participação de grupos filantrópicos. Programas que visavam à qualidade de vida dos presos, a construção de estabelecimentos mais dignos e profissionais mais capacitados para lidarem com essa demanda. (MUAKAD, 1998).

Desde a sua constituição, as bases do sistema continuam as mesmas: disciplina exaustiva, horários controlados, submissão total, precarização alimentar de bens e serviços oferecidos. Todos estes fatores associados à falta de políticas de educação nos presídios, ausência de equipe médica interdisciplinar, trabalho digno, a visão do preso como um cidadão de direitos apontam para o fracasso das prisões desde o seu surgimento.

Isso, porque desde a sua gênese, as prisões não tinham o intuito de melhorar os indivíduos para posteriormente recolocá-los na sociedade de uma forma mais digna e melhor. Elas buscavam afastar os sujeitos do convívio social, numa tentativa de esconder

\footnotetext{
${ }^{2}$ O Conselho Nacional de Política Criminal e Penitenciária estipulou em 1995 uma reincidência de $85 \%$ dos presos que passam pelo sistema penitenciário brasileiro.
} 
as injustiças e erros produzidos pela própria sociedade. Dentro do estabelecimento carcerário, as promessas de programas e projetos sociais, médicos e outros serviços são substituídos pela depreciação do ser humano.

As taxas de criminalidade e reincidência são crescentes e de uma forma mais aguda nos últimos anos, vem atingido até crianças e adolescentes. A discussão sobre a redução da menoridade penal de 18 para 16 anos, permeia o fracasso das prisões brasileiras, pois até mesmo os Centros de Reabilitação para Menores vem sendo atingidos pela falta de programas e políticas eficazes, que resultam a reincidência criminal e aumento da criminalidade.

Se as prisões não têm cumprido o seu principal papel de recuperar os indivíduos e devolvê-los à sociedade de uma forma melhor, por que o encarceramento ainda é aceito como forma de punição? Um dos motivos é que as prisões não respondem aos anseios e necessidades do grupo carcerário, mas de uma elite dominante, tanto política como economicamente, que possui interesses em manter os criminosos presos para demonstrar o seu poder de dominação dentro da sociedade.

O momento histórico da consolidação das prisões é o mesmo do aumento das fábricas e dos avanços tecnológicos da revolução industrial. O mercado de trabalho expande exorbitantemente e necessita de toda forma de força de trabalho, inclusive de minorias como mulheres, crianças e detentos. A prisão aparece como meio privilegiado de transformar pessoas ociosas em uma população trabalhadora. (CAMARGO, 1990).

Na consolidação da sociedade pós-industrial, no final do século XVIII e o início do século XIX, a sociedade capitalista não vê mais vantagem na sanção física. As penas são adotadas como forma de civilização e o trabalho tem a função de atenuar a ociosidade, além de ser justo já que o delinqüente gera custas ao Estado.

Como o capitalismo necessita de força de trabalho, o cárcere surgiu para acolher os acusados à espera de condenação e condenados à espera de execução penal. Essas pessoas surgem como uma mão de obra fácil de ser explorada.

Hoje o trabalho penal não possui as mesmas características do século passado. Os trabalhos não são forçados e nem submetidos à tortura ou violência física como anteriormente. Denúncias de utilização de mão de obra dos presos de forma escrava são raras.

O que ainda constitui o trabalho como uma forma de exploração são as condições em que estas atividades são executadas. O imperativo de mão de obra qualificada e preparada é muito alto dentro da conjunção do sistema capitalista, o que faz 
com que esse grupo de indivíduos, que está na condição de apenado, não possa pleitear as mesmas vagas das demais pessoas.

Os presos no Brasil têm sido manejados como se o delito cometido fosse um fato isolado na sua trajetória de vida, sendo que o crime é apenas resultado de uma trajetória marcada pela distância de políticas e programas do Estado. Eles carregam a falta de qualificação, o despreparo e o estigma das pessoas que já estiveram recolhidas no sistema penitenciário.

Geralmente, ao terminarem o cumprimento da pena, retornam ao mercado de trabalho no estado periférico e executando as tarefas mais desqualificados profissionalmente e de pior remuneração. Seus direitos trabalhistas são desrespeitados e os benefícios adquiridos e consolidados historicamente são ignorados.

Este é o grande motivo do fracasso das prisões, porque ele não propicia condições dignas da pessoa manter-se após os anos de recolhimento. O número de reincidência criminal é crescente porque muitos destes cidadãos têm no retorno ao mundo da criminalidade uma forma de sobrevivência. 


\section{A construção histórica do Direito}

\subsection{Lei X Direito}

Um dos grandes problemas enfrentados no cumprimento das penas privativas de liberdade no Brasil é que a sociedade incutiu a falácia, de que os detentos não são sujeitos de direitos, são apenas delinqüentes, e, portanto, não são dignos e nem merecedores de qualquer forma de assistência ou auxílio na reinserção social.

Contrapondo-se a essa idéia, existem inúmeras legislações que assegurem direitos específicos para os sentenciados, como é o caso da Declaração Universal dos Direitos Humanos (1948), o Código Penal Brasileiro (1940) e principalmente a Lei de Execuções Penais (1984). Elas garantem o cumprimento da pena em condições dignas, acesso ao mercado de trabalho, educação, acompanhamento psicológico, médico e outros benefícios.

Logo, podemos concluir que nem sempre existe uma correlação entre o direito e a lei. No caso do Brasil, este distanciamento tem a sua gênese no significado destas palavras, pois embora os termos sejam diferentes, os significados são adotados como sinônimos: Direito "é a ciência das normas obrigatórias que disciplinam as relações do homem em sociedade; jurisprudência” e Lei "é a obrigação imposta pela consciência e pela sociedade”. (AURELIO, 2001).

Em outros idiomas existem palavras diferentes para definir os conceitos distintos, como os exemplos que significam respectivamente Direito e Lei: Latim - Lus e Lex, Espanhol - Derecho e Ley, Francês - Droit e Loi, Russo - Pravo e Zakon, Alemão, Recht e Gesetz. (FILHO, 1986).

Para compreendermos tais conceitos e as suas devidas implicações, temos que analisar a forma de organização da nossa sociedade. Dentro de todos os grupos existem diferenças. Alguns acreditam que uma determinada atitude é correta e benéfica para o todo. Outros acreditam que a mesma ação não é positiva. Uns possuem habilidades naturais, estrutura familiar e outros elementos que possibilitem manter as necessidades básicas. Mas existem pessoas que carecem de uma intervenção externa para garantir sua sobrevivência.

Diante dessas diferenças individuais que se expressam no coletivo é que a sociedade necessita de princípios reguladores, que são os direitos. (TELLES, 1994). Ele 
será a barreira entre o certo e o errado, entre o permitido e o punido, com base nas próprias relações sociais, nos valores, nas práticas e nos discursos.

A autora acrescenta que, os direitos são resultado da história, são produto da luta da sociedade diante de uma determinada demanda. Como ocorreu no início do século XIX, onde os trabalhadores trabalhavam em jornadas de 14 horas diárias. A mobilização e luta pela fixação de uma jornada de trabalho legal e digna, fez com que isso se tornasse um direito usufruído ainda nos dias atuais.

Quando as representações das necessidades, demandas e anseios da população ou de grupos com uma necessidade específica, são assumidas por instituições que detém o poder de normatização, temos a Lei.

A Lei emana do Estado e está intrinsecamente ligada às classes e grupos politicamente dominantes. O Estado é o órgão centralizador do poder, por isso ele tem o poder de legislar, implementar e punir. (FILHO, 1986). Dentro da atual estrutura capitalista, o poder político está fortemente relacionado ao poder econômico.

O autor relata ainda, que para os positivistas, a raiz da elaboração jurídica está na ordem, isto é, todo conjunto de indivíduos necessita de uma ordem que estabeleça o certo e errado. Este é o mínimo para a existência humana e a base para se alcançar a justiça

O positivismo é uma redução do Direito à ordem estabelecida, por isso esta corrente possui tantos adeptos do sistema capitalista, porque buscam adequar o sujeito às normas e regras estabelecidas, aqueles que por algum motivo não se aderem ao sistema, são considerados “desviados” ou “desajustados”, a explicação do fracasso individual está no âmbito individual e o coletivo se isenta de qualquer responsabilidade.

A estrutura sócio-político vigente é a da exploração material e intelectual. Quando o capitalista se apropria da força de trabalho do individuo, conseqüentemente ele incute que os seus valores, as suas idéias e as suas práticas são melhores, tornando os trabalhadores sujeitos de manipulação.

Justamente por estar permeada de interesses distintos é que não podemos dizer que as leis expressam de forma clara e concreta os direitos legítimos. Elas sofrem a intervenção da dominação de grupos, idéias, valores e outros fatores que expressam o poder.

Com o passar do tempo, as leis de cada grupo mudam, porque as suas necessidades vão se alterando ao longo dos anos. Mas o Direito, que é a essência 
manifestada na Lei, permanece, mesmo que em um dado período ele não esteja manifesto na legislação. (FILHO, 1986).

\subsection{Direitos Civis, Políticos e Sociais do Preso}

O sociólogo britânico T. H. Marshall compreendeu a dimensão dos direitos de uma forma histórica e contínua, e definiu um processo de consolidação da cidadania, que se inicia com a obtenção dos direitos civis, passa pelos direitos políticos e chega aos direitos sociais. Nesta perspectiva, poderemos analisar que os sentenciados não usufruem nenhuma dessas categorias de direitos.

\subsubsection{Direitos Civis}

Os direitos civis também podem ser conhecidos como direitos naturais. A corrente jus naturalista acredita que o simples fato de um sujeito nascer, independente da posição social ou poder econômico que ele possui, o faz detentor de direitos. São eles: o direito à vida, à liberdade, à igualdade, à segurança, à propriedade. (COUTINHO, 1997).

A Constituição Federal Brasileira (1988) traz em seu artigo $5^{\circ}$ os direitos citados acima, como fundamentais. Mas na prática, a maioria da população brasileira não usufrui deles. Isso porque, os direitos civis não são dados e sim conquistados, embora estejam consolidados em Lei.

No caso do segmento da sociedade, que cumpre pena privativa de liberdade, esses direitos são praticamente inexistentes. É fato que quando um sujeito comete um crime, ele deve responder pelos atos cometidos, o que justifica a perda do direito de liberdade.

Neste caso, a liberdade de ir e vir. De cumprir seus próprios horários, escolher seu local de moradia, definir sobre o curso da sua vida. O sentenciado perde o direito da livre escolha, baseado na justificativa que quando ele comete um delito, essas decisões devem ser tomadas pelo Estado e não mais por ele.

Mas o Estado, como qualquer outro tipo de organização formada por pessoas, possui seus interesses próprios e particulares, que se opõem aos interesses da classe de sentenciados. Conseqüentemente, cabe aos presos brasileiros a decisão de aceitar as imposições governamentais, embora sejam incompatíveis com seus direitos fundamentais e civis. 


\subsubsection{Direitos Políticos}

O conceito de Direito Político teve o seu desenvolvimento associado ao conceito de cidadania. As primeiras teorias surgiram na Grécia Clássica, onde o cidadão era o indivíduo que participava ativamente da esfera pública, exercendo cargos, tomando decisões e contribuindo para a formação do governo.

A cidadania tinha a sua expressão maior no direito de votar e se fazer votado. Uma dimensão que não era universal, pois excluía os escravos, mulheres e estrangeiros, uma parcela da população que representava aproximadamente três quartos do total. Notamos, que os Direitos Políticos e a Cidadania eram direitos restritos e não universais. (COUTINHO, 1997).

Hoje este conceito está mais ampliado. O autor citado anteriormente, explica que além do direito de votar e ser votado, o Direito Político engloba também uma esfera que até o final do século XIX foi negada à maioria da população, a possibilidade de associação e organização em grupos e categorias específicas.

O sufrágio universal no Brasil só foi consolidado na Constituição Federal de 1988, quando os analfabetos foram incorporados como cidadãos. Essa conquista foi possível graças à luta de movimentos sociais, que não se conformavam com a realidade imposta que acredita que a organização levaria à mudança da estrutura vigente.

Inúmeros direitos foram consolidados pela população, com a organização e a participação nas decisões que envolvem o conjunto da sociedade. Sua importância é inegável. Mas quando nos reportamos aos presos no Brasil, vemos que esse direito fundamental é negado.

O artigo 15 da Carta Magna diz:

É vedada a cassação de direitos políticos, cuja perda ou suspensão se dará nos casos de: I. cancelamento da naturalização por sentença transitada em julgado; II - incapacidade civil absoluta; III - condenação criminal transitada em julgado, enquanto durarem seus efeitos; IV - recusa de cumprir obrigação a todos imposta ou prestação alternativa, nos termos do art. $5^{\circ}$, VIII; V - improbidade administrativa, nos termos do art. 37 , § $4^{\circ}$.

O dispositivo é claro, basta uma sentença criminal condenatória para o cidadão perder os seus direitos políticos, fruto de lutas e reivindicações históricas. A perda está associada à sentença e não à pena, por isso, o sentenciado à multa, pena alternativa e privação de liberdade tem a mesma penalidade: a perda do direito político. 
A impossibilidade de votar é justificada pela dificuldade de locomoção das urnas de votação. Mas a falta de organização da categoria, que também é um direito político, não possui justificativa. Essa mobilização como grupo específico é responsabilidade dos próprios indivíduos, mas o Estado deve proporcionar meios para que isso ocorra.

Certos grupos já adquiriam seu espaço dentro da sociedade, e isso independe dos valores existentes. Podemos citar como exemplo, os homossexuais que publicamente lutam pelo direito de adotarem filhos, terem casamentos reconhecidos pelo Estado e não sofrerem discriminação. Tudo isso é conseqüência da união como categoria por um objetivo em comum.

A falta de acesso à informação sobre os direitos pessoais e coletivos é a principal causa da estagnação. Neste ponto, os movimentos sociais e de classe são fundamentais para a efetivação de reinvidicações, mas também não são pauta de interesse da classe dominante em divulgar tais informações, pois desta forma, torna-se mais fácil manipular os indivíduos.

No Brasil, não temos movimentos similares na categoria dos presos. Embora todos saibam e a mídia noticie frequentemente as privações que eles sofrem. Mas pensar na luta pelos direitos humanos para os presos, em passeatas pelas ruas, em familiares exigindo na Câmara e no Senado Federal os direitos dos internos, ainda é utópico. Essas exigências vêm sendo feitas pelos profissionais que lidam com a temática.

\subsubsection{Direitos Sociais}

Direitos Sociais são as práticas que permitem os sujeitos terem participação na produção da sociedade, bem como, nas conseqüências subjetivas que elas geram. Na modernidade, a educação pública e universal, foi a primeira política reconhecida como direito social. (COUTINHO, 1997).

Com o passar dos anos e graças às lutas dos trabalhadores, outros direitos foram se consolidando como a saúde, habitação, previdência social, assistência social e trabalho, o que gerou o chamado Estado de Bem Estar Social ou Welfare State.

Os Welfare States têm a sua gênese em países onde o capitalismo já estava consolidado, no período pós-guerra. Mas nas sociedades pré-capitalistas já existiam iniciativas sociais, ligadas ao "dever cristão”, à caridade, sendo desenvolvidas de formas pontuais e geralmente individuais. (PIERSON, 1988). 
Neste período, o Estado não se envolvia com a economia e nem se responsabilizava com a questão social. O objetivo das ações sociais que existiam não era garantir direitos, mas sim, manter a ordem pública e punir a vagabundagem. A intervenção do governo era somente para aqueles que não possuíam condições físicas para trabalhar, como deficientes físicos.

Os pobres e os mendigos "válidos" eram considerados vagabundos, porque tinham condição de se inserir no mercado de trabalho e não o faziam. O debate entre trabalho e direitos sociais, que ainda está em discussão nos dias atuais, é oriundo deste momento histórico. (BOSCHETTI, 2003).

Ainda hoje, muitas pessoas não acham justo uma pessoa que possui capacidade física e mental para trabalhar, receber auxilio de programas sociais do governo. O Estado Social é condenado por estimular a ociosidade e a dependência, sendo prejudicial ao desenvolvimento econômico do país.

Quando analisamos especificamente a categoria dos presos brasileiros, essa situação se agrava. Os direitos sociais desta parcela da população são restringidos. Dentro do sistema penitenciário, o acesso à educação, saúde, alimentação digna, habitação são praticamente inexistentes, como relataremos mais precisamente nos próximos capítulos.

E por serem considerados como "válidos” para o mercado de trabalho, não recebem direitos como assistência e previdência. Mas como estão recolhidos prisionalmente, não possuem condições de se inserir no mercado de trabalho de forma digna e viver à custa do seu próprio salário.

A ampliação dos direitos se opõe à lógica do capital, por isso as leis vão de encontro aos interesses de poucos. Nesta perspectiva, o trabalho externo, como direito, não vem beneficiar o sentenciado que necessita de trabalhar para suprir suas necessidades materiais e espirituais, mas para manter a exploração do capital.

As características assumidas pelo trabalho dos presos, acabam ampliando as conseqüências da pena, porque atingem outras áreas da vida do indivíduo, além da limitação do direito de ir e vir.

O direito do sentenciado é substituído pelos interesses do Estado. Tal relação é colocada como legal e normatizada pela Lei de Execução Penal, que, ao invés de manter os direitos trabalhistas estabelecidos pela Consolidação das Leis Trabalhistas, reduz os direitos do trabalhador na condição de apenado ao salário mensal. 
As oportunidades de trabalho são reduzidas à atividades que exigem muito esforço físico, como na área da construção civil e mecânica. O sentenciado é visto como um trabalhador braçal que possui baixo poder cientifico e criativo, categorizando uma perda de direito de escolha.

\subsubsection{Direitos X A desresponsabilização do Estado}

Com o acirramento do capitalismo questões relacionadas com a pobreza, miséria e precariedade passam da pauta social para a política. O Estado precisa intervir a fim de manter o acesso da população a bens e serviço e proporcionar a distribuição das riquezas.

Os investimentos na área social e da saúde vêm sendo responsabilizados pelo déficit público, pelo desequilíbrio das contas do governo e por isso devem ser reduzidos. A política neoliberal acredita na mínima intervenção estatal no mercado e as expressões da questão social seriam solucionadas no próprio mercado ou pela participação da sociedade civil.

Segundo Gramsci, sociedade civil é o conjunto de organizações que visam garantir seus direitos, é um espaço de difusão de ideologias e de mediação entre a esfera econômica e o Estado de coerção (COUTINHO, 1999). De acordo com o autor, o Estado só alcança seu sentido amplo quando a esfera política, isto é, o uso da coerção por meio dos aparelhos ideológicos para a manutenção dos interesses da classe dominante, se une à sociedade civil.

Na tentativa de diminuir os gastos na área social, o Estado começa a estimular a sociedade civil para o enfrentamento das expressões da questão social, numa falsa privatização da Questão Social. (ALMEIDA, 2004). Desta forma ele se desresponsabiliza do seu papel de recolocar o sentenciado no mercado de trabalho e de qualificá-lo de uma maneira adequada para propiciar um emprego de melhores condições.

As empresas assumem a tarefa da ineficácia do Estado, agravada pelos anos de recolhimento prisional e a falta de acesso à políticas de saúde, alimentação adequada e qualificação profissional. A motivação das instituições não está pautada na 
responsabilidade como sociedade civil, mas sim nos laços afetivos que existem com o sentenciado.

O trabalho externo do sentenciado não foge à lógica da participação da sociedade civil na era neoliberal. A responsabilidade de oportunizar vagas de trabalho para os presos egressos não é da sociedade civil, mas sim do Estado. A participação da sociedade civil é fundamental na solução dos problemas sociais, mas este setor não pode ser responsabilizado e sim motivado a empregar sentenciados. Lutar contra o preconceito, estigma do sentenciado, a baixa qualificação profissional dentre outros fatores. 


\section{Trabalho}

\subsection{As metamorfoses do mundo do trabalho}

No início do século XIX, o mundo começa a sofrer profundas mudanças estruturais. A economia que antes era baseada na produção artesanal aos poucos adere ao maquinário como mecanismo para acelerar a produção. Este processo de industrialização não afeta somente o âmbito material da vida dos indivíduos, mas as suas relações sociais, culturais, morais e familiares implicando em novos modelos de vida.

O trabalho na era do capitalismo tem uma função que vai além da produção de um serviço ou um bem de consumo, ele é um instrumento que define classes, posições sociais, status e ajuda a adaptar o indivíduo a um determinado grupo (ANTUNES, 2001).

O trabalho se constitui como necessidade humana e social. A categoria trabalho é mais do que o conjunto de atividades desenvolvidas e produzidas no decorrer do dia, mas sim, o processo social de transformação que visa atender necessidades sociais e humanas (MARX,1988).

O que diferencia o trabalho no capitalismo, das demais formas de produção é que o trabalho deixa de possuir somente valor de uso, que atende as necessidades do indivíduo e passa a ter valor de troca. O capitalista detém o controle sob o modo de trabalhar e sobre o produto dessa atividade.

Na gênese deste modo de produção, a busca pelo aumento da lucratividade das indústrias foi baseada na exploração física do trabalhador e de segmentos da sociedade que não estavam inseridos no mercado de trabalho, como crianças, mulheres, idosos e deficientes físicos.

Crianças de 7 a 14 anos eram consideradas aptas para desenvolver atividades penosas nas fábricas, por serem pequenas e ágeis. Aos demais trabalhadores restava trabalhar sem condições de higiene, com baixos salários, jornadas de trabalho que chegavam à 14 horas diárias, sem descanso, sem direito algum. A conseqüência era o enriquecimento da pequena parcela da sociedade, dona das fábricas e indústrias e a maioria da população composta por trabalhadores miseráveis e carentes. (MARX, 1975).

No decorrer dos anos, os trabalhadores se uniram como classe e aos poucos foram mudando este quadro. Lutaram pelo seu espaço social e político e gradativamente adquiriram direitos que foram consolidados e positivados, melhorando a situação 
empregatícia e a sua posição social e política na sociedade.

As autoras Elaine Behring e Ivanete Boschetti, em seu livro Política Social: fundamentos e história, de 2006, traçam uma trajetória das conquistas deste período:

- 1919: Legislação de acidente de trabalho - Até este período, os acidentes de trabalho eram considerados caso de polícia, por isso, era necessário se abrir inquérito policial para averiguar as causas e os culpados dos acidentes, como conseqüência as indenizações eram tardias.

- 1923: Legislação que assegurava o pagamento de salários aos trabalhadores idosos, inválidos, em casos de falecimento e auxílio maternidade. Os recursos eram oriundos das caixas dos ferroviários.

- 1940: Lei do Salário Mínimo

- 1943: Criação da Consolidação das Leis Trabalhistas-CLT

Os exemplos citados são apenas parte de uma gama de conquistas vivenciadas neste período histórico. Esses direitos conquistados nas primeiras décadas do século XIX são válidos nos dias atuais, como forma de proteção aos riscos do mercado de trabalho e àqueles que não estão inseridos no mercado, como crianças, deficientes e idosos.

Mas as mudanças que ocorreram no mundo do trabalho, principalmente nos anos 80, acarretaram em alterações na forma como esses direitos já consolidados vão se expressar na sociedade nos anos posteriores.

Essa década foi palco de grandes mudanças, especificamente do avanço tecnológico, da robótica, da eletrônica, da globalização e de outros mecanismos de aceleração no processo produtivo. O just time e a produção em massa, típicos do fordismo e do taylorismo ${ }^{3}$ são substituídos pelo padrão de acumulação flexível, também denominado de toyotismo ${ }^{4}$

Surgem novas formas de buscar os resultados positivos dos anos de ouro do capitalismo. A rigidez e a violência física no início do século dão lugar à gestão participativa, à busca de qualidade de vida do trabalhador, programas de motivação, adequação ao trabalho e qualidade total. (ANTUNES, 2001).

\footnotetext{
${ }^{3} \mathrm{O}$ fordismo é o modelo conhecido como a produção em série, onde cada trabalhador detém apenas uma etapa da produção. O taylorismo é o modelo onde se busca a eliminação dos excessos da produção, just time, tudo tem o seu tempo certo, não existem estoques e nem sobram no processo, tudo para maximizar os lucros.

${ }^{4}$ Uma nova forma de organização da produção que combina novas técnicas de gestão com um maquinário cada vez mais sofisticado, visando o aumento da produção e a redução do número de empregadores
} 
$\mathrm{O}$ autor acrescenta, que o desenvolvimento de novas tecnologias gerou o excedente de força de trabalho, por isso, o trabalhador deve ser cada vez mais qualificado, possuir conhecimento sobre a sua área de atuação e desempenhar funções que não são originalmente as suas.

O trabalho "polivalente”, "multifuncional”, combinado à uma estrutura horizontalizada, busca de formas variadas a mesma exploração do trabalho do início do capitalismo. Tudo isso, para manter um lugar no mercado de trabalho, que está cada vez mais concorrido e exigente.

Neste processo de flexibilização da produção, os direitos citados anteriormente, também sofrem modificações. O desemprego alcança $10 \%$ da população economicamente ativa (RADAR SOCIAL, 2005), o mercado informal, isto é, o espaço onde o trabalhador não possui proteção social, é crescente e atinge 51,4\% dos trabalhadores em 2005. (IPEA, 2005).

A segurança vitalícia e a estabilidade empregatícia cedem espaço para os contratos temporários. Direitos como férias, décimo-terceiro, FGTS, auxílio maternidade, horário pré-estabelecido, período de almoço e muitos outros, em alguns casos são substituídos somente pelo salário mínimo.

Determinados segmentos da sociedade sofrem de forma mais acentuada com essa flexibilização da produção e, conseqüentemente, dos direitos. Indivíduos que durante a sua trajetória de vida não tiveram acesso a bens e serviços básicos, como saúde, alimentação, moradia e principalmente educação, não possuem formação profissional suficiente para concorrer aos cargos que garantem direitos e estabilidade.

Por isso, o mercado informal é acima de tudo um mercado de sobrevivência e não de escolha. É a alternativa dada a esses indivíduos de se manterem e sustentarem a sua família, diante dos problemas estruturais vivenciados.

Outro segmento que sofre diretamente as conseqüências dessas mudanças no mercado de trabalho são os trabalhadores presos. A maioria dos sentenciados é pertencente às camadas menos favorecidas economicamente, possuem baixa qualificação profissional e poucos anos de estudo (Ver quadro 2 pág 36).

Por esta razão, grande parte dos sentenciados antes do recolhimento prisional, estavam desempregados ou inseridos no mercado informal e conseqüentemente vão se enquadrar nele após o cumprimento da pena, caso nada seja feito para mudar esta perspectiva. 


\subsection{O trabalho interno}

Dentro do sistema carcerário, o trabalho aparece como uma forma de diminuir o ócio e gerar algum tipo de renda para os presos. Mas as atividades não fogem à lógica da perda de direitos, da exploração disfarçada e da dominação de classes que vem se arrastando desde o início do século.

O trabalho é um direito social. Mas para os sentenciados é um benefício, como discorre a Lei de Execução Penal. Diante da escassez de vagas, poderíamos chamá-lo de "benefício do benefício”. Dentro desta lógica, existem duas formas de trabalho, o intramuros e o extra muros.

Internamente o sentenciado trabalha primordialmente com o intuito da remição, a cada três dias de atividades laborais um dia da pena é diminuído. (LEP, art. 37). Os sentenciados precisam ser previamente classificados pelo presídio ou pela FUNAP - Fundação Nacional de Amparo ao Preso.

Tal classificação nem sempre está fundada em critérios objetivos; o principal critério é o mérito, compreendido pelo sistema penitenciário como a obediência e a submissão ao regime disciplinar e a "simpatia” dos agentes penitenciários e policiais pelos sentenciados.

Poucos postos de trabalhos são remunerados. Aqueles que acabaram de ingressar no serviço recebem $75 \%$ do salário mínimo, depois passam para $80 \%$ até alcançarem a totalidade do valor. Este pagamento é dividido em três partes: 1/3 o sentenciado recebe em espécie no presídio, 1/3 fica com algum responsável da família e 1/3 é colocado em uma poupança que só poderá ser retirado após o cumprimento da pena.

Teoricamente o bom comportamento é o grande diferencial entre aqueles que irão trabalhar e que terão o ócio como companheiro de sentença. Na prática, em média 17,8\% dos presos tem o "privilégio" de se ocuparem com alguma atividade durante o dia, como limpeza predial e das celas, distribuição da alimentação, atividades nas fábricas existentes dentro do presídio, atendimento na cantina e triagem dos apenados para tratamento de saúde (CARDOSO, 2006).

O quadro abaixo mostra a quantidade de presos em programas de trabalho interno no final do ano de 2006, no Distrito Federal. 


\section{Quadro 1: Áreas de trabalho interno}

\begin{tabular}{|l|l|l|l|}
\hline Atividade & Sexo Masculino & Sexo Feminino & Total \\
\hline Artesanato & 17 & 22 & 39 \\
\hline $\begin{array}{l}\text { Apoio ao estabelecimento } \\
\text { penal }\end{array}$ & 783 & 130 & 913 \\
\hline Atividade Rural & 20 & 0 & 20 \\
\hline Outros & 315 & 0 & 315 \\
\hline Total & 1135 & 152 & 1287 \\
\hline
\end{tabular}

Fonte: Infopen, 2006

Nota-se que a maioria das atividades é de apoio ao estabelecimento penal, que não proporcionam o aprendizado de novos conhecimentos e nem exigem qualificação profissional. As oficinas de trabalho, como reciclagem de lixo e produção de sacos plásticos, que são atividades mais reconhecidas e valorizadas, oferecem poucas vagas.

Os demais têm como alternativa o mercado paralelo que existe nas prisões; como venda de materiais de higiene, vestimentas, serviços de lavagem de roupa, alimentação, drogas e até mesmo espaços físicos no pátio para receber as visitas ou dentro das celas para pernoite.

A classificação dos internos reforça o senso comum de que aqueles que trabalham são sujeitos honrados e de moral e aqueles que não trabalham são vagabundos. Logo, aqueles sentenciados que não são classificados carregam dois estigmas negativos, o do preso e o do preso vagabundo.

\subsection{0 trabalho externo}

O trabalho externo está inserido na progressão de regime do Código Penal Brasileiro, que possui duas fontes de inspiração:

\subsubsection{O modelo progressivo inglês}

O modelo de progressão de regime, onde o trabalho externo está inserido, 
data do ano de 1846. Machonochie, capitão da Marinha Inglesa, experimentou um novo sistema, o Mark System, na ilha de Norfolk e acabou dando origem a progressão de regime que a Execução Penal admite no Brasil (MUAKAD, 1998).

A pena é divida em três regimes: o inicial é cumprido de forma rígida, através de trabalhos penosos durante o dia e isolamento das celas no período noturno; a segunda fase, trabalho comum durante o dia sob a regra do silêncio e pernoite na prisão, e o terceiro todo o período é cumprido em liberdade. (SILVA, 2003).

\subsubsection{O modelo progressivo irlandês}

Surge em 1853, com o irlandês Walter Crofton que tinha como principal objetivo preparar o preso para o retorno ao convívio social. Os presos eram encaminhados para prisões intermediárias, com vigilância menos rígida, sem uso de uniformes, sendo livre o diálogo e as saídas para o trabalho diurno. (SILVA, 2003).

\subsubsection{O modelo progressivo brasileiro}

Inspirado em ambas correntes, o Brasil adotou que o trabalho externo, só pode ser concedido após a progressão do regime do fechado para o semi-aberto ou para aqueles que já foram condenados no regime mais brando.

Para que isso ocorra, o sentenciado deve cumprir no mínimo $1 / 6^{5}$ do total do tempo da pena, que significa o caráter objetivo para o pleito do benefício. O caráter subjetivo é o bom comportamento do preso e que o trabalho seja desenvolvido em uma empresa idônea.

O sentenciado originalmente trabalha pela FUNAP que possui parcerias com órgãos públicos ou em empresas privadas, caso a família consiga articular uma vaga para o seu familiar.

\subsection{Trabalho penal: Parte da Pena ou Benefício?}

\footnotetext{
${ }^{5}$ Desde o dia 09/03/2006 com 1/6 de cumprimento de pena o sentenciado pode requerer a progressão de regime para o semi-aberto, mesmo o crime sendo hediondo. Ainda existe uma grande discussão em torno da temática, pois alguns profissionais acreditam que os efeitos da progressão seriam mais positivos caso ela fosse deferida após o cumprimento de $2 / 5$ do total da pena.
} 
Independente do trabalho do sentenciado ser desenvolvido interna ou externamente, a discussão que permeia essas atividades é se o trabalho do sentenciado é apenas parte de suas obrigações como apenado, ou se é um benefício, uma vantagem que ele recebe por bom comportamento e outros critérios, ou se é o reconhecimento do seu direito como cidadão.

Foucault (1987) inicia essa discussão quando explica que na França do século XIX, os presos recebiam remuneração pelos seus trabalhos, por isso as atividades laborais não poderiam ser consideradas como parte da pena, já que existia uma recompensa econômica.

Por outro lado, se considerarmos o trabalho como um benefício, estaremos recompensando as habilidades naturais e individuais dos presos e não a regeneração pelo delito cometido. Logo, a mão de obra do preso, deve competir com as demais que existem no mercado de trabalho.

Quando analisamos a estrutura dos presídios do Distrito Federal, as necessidades dos sentenciados e como o Estado vem respondendo a essas questões, notamos uma nítida escassez de políticas e programas que visem tratar a questão do indivíduo e da prática do crime.

Os presídios não possuem instalações dignas, alimentação adequada, nem mesmo atendimento médico e odontológico suficiente para toda a população carcerária. O serviço de profissionais especializados, como Assistentes Sociais e Psicólogos dentro das prisões, são apenas medidas paliativas ou em casos de emergência, porque falta escolta para esses profissionais realizarem seus atendimentos dentro e fora do estabelecimento (CARDOSO, 2006).

Por isso, existe essa ênfase tão grande no trabalho penal, porque ele é visto como o único programa oferecido pelo Estado, que pode produzir novos hábitos, novos valores e uma nova forma de vida ao indivíduo, além de produzir a ressocialização e o retorno ao convívio social, por vezes, substituindo toda uma trajetória de ausência de políticas específicas.

O trabalho é a centralidade das relações sociais (MARX, 1987) porque é através dele que a pessoa estabelece seus laços e estrutura o seu modo de vida. No modelo capitalista, o trabalho tem essa função central, porque a atividade natural de transformação da natureza passa de valor de produção para valor de troca.

Logo, a força de trabalho é vista como mais uma mercadoria dentre tantas que podem ser compradas, vendidas e conseqüentemente, exploradas. O capitalismo expressa 
a ideologia e os estereótipos que existem em torno das profissões, até mesmo inferências sobre o caráter humano são feitas somente pelo trabalho que uma pessoa exerce.

No cumprimento de pena, o trabalho ajuda a disciplinar os indivíduos e a estabelecer os padrões que são corretos. É uma das melhores formas de moldar os sujeitos de acordo com o que a classe dominante estabelece, porque ele age sobre o modo de viver e pensar da pessoa.

Por isso, podemos concluir que o trabalho é parte fundamental no cumprimento da pena, mesmo que no regime semi-aberto ele seja concedido como benefício. Mas somente o trabalho não pode ser a solução de uma trajetória de ausência de programas, atendimentos básicos e falta de direitos.

Para que o trabalho realmente cumpra o seu papel de ressocialização, ele deve ser associado principalmente, com uma educação de qualidade. Os presos devem ter acesso ao ensino formal, isto é, aos conhecimentos exigidos em um mundo cada vez mais competitivo, o aprendizado dos números e das letras e das matérias regulares.

Pois a baixa escolaridade e a falta de qualificação profissional dos sentenciados tem sido um dos maiores desafios dos profissionais que buscam a integração no mercado de trabalho.

O próximo quadro revela como a falta de escolaridade atinge diretamente os sentenciados do Distrito Federal:

\section{Quadro 2: Quantidade de Presos por Grau de Instrução}

\begin{tabular}{|l|l|l|l|}
\hline Escolaridade & Sexo Masculino & Sexo Feminino & Total \\
\hline Analfabeto & 343 & 13 & 356 \\
\hline Alfabetizado & 132 & 5 & 137 \\
\hline Ensino Fundamental Incompleto & 4531 & 203 & 4734 \\
\hline Ensino Fundamental Completo & 757 & 31 & 788 \\
\hline Ensino Médio Incompleto & 627 & 32 & 659 \\
\hline Ensino Médio Completo & 376 & 32 & 408 \\
\hline Ensino Superior Incompleto & 88 & 02 & 90 \\
\hline Ensino Superior Completo & 14 & 01 & 15 \\
\hline Ensino Acima de Superior Completo & 01 & 0 & 01 \\
\hline Não Informado & 30 & 0 & 30 \\
\hline
\end{tabular}




\begin{tabular}{|l|l|l|l|}
\hline Total & 6899 & 319 & 7218 \\
\hline
\end{tabular}

Fonte: Infopen, 2006

Podemos observar que a maior parcela possui apenas o Ensino Fundamental Incompleto, correspondente aos primeiros anos de estudo. Atualmente, esta escolaridade representa pouco no momento de inserção no mercado de trabalho, onde as empresas exigem cada vez mais qualificação por parte dos seus funcionários.

Para que a mão de obra do preso seja competitiva no mercado e realmente possa possibilitar o seu sustento e de sua família de forma justa e digna é fundamental que se invista em educação de qualidade, agindo sobre a maneira de pensar e agir dos indivíduos. Produzir novos valores, estruturar conceitos e posteriormente, mudar a prática dos atos cometidos.

As pessoas que infringem a lei, muitas vezes o fazem porque o meio em que ela convive aceita certas práticas como corretas, algumas vezes, até como meio de sobrevivência. O furto, o roubo e o uso de substâncias entorpecentes em determinadas comunidades, é considerado como padrão “normal”, diante do alto índice de violência e criminalidade que estes grupos enfrentam.

O papel dos Educadores, Assistentes Sociais, Psicólogos e demais profissionais é levar aos sentenciados um novo modo de vida, proporcionar e auxiliar nas mudanças que são necessárias em âmbito individual e coletivo. Lutando pela ampliação dos espaços educacionais, por oficinas de trabalho, palestras educativas e pelo acompanhamento do cumprimento das penas. 


\section{Análise dos dados da pesquisa}

\subsection{O trabalho dos presos em empresas privadas}

O trabalho extra muros é uma concessão para os sentenciados em regime semi-aberto que apresentam bom comportamento. As vagas são resultado de parcerias com órgãos do governo, administrações regionais, hospitais e escolas públicas ou qualquer outra instituição governamental cadastrada junto à FUNAP.

Esta fundação tem a função de estabelecer convênios com entidades públicas objetivando a reinserção do sentenciado no mercado de trabalho, tanto do preso em regime semi-aberto, como o egresso que está cumprindo pena em regime aberto, que é o livramento condicional ou prisão domiciliar e acompanhar o desenvolvimento do trabalho, incluindo assistência ao trabalhador. Além de proporcionar a estrutura para o trabalho intramuros, como relatamos nas páginas anteriores.

Mas a dificuldade de acompanhamento dessas atividades tem sido a maior responsável pelo fechamento de postos de trabalho, como mostra o Projeto FUNAP 2005. No período entre março de 2001 a outubro de 2004, surgiram 1849 oportunidades de trabalho para os sentenciados, 1735 começaram a trabalhar. 1195 (68,87\%) foram desligados, deste total 241 (20,16\%) por motivos positivos e 954 (79,83\%) por motivos negativos. $^{6}$

Diante deste quadro, esporadicamente, alguns advogados procuravam entre os familiares e conhecidos do sentenciado, alguém que pudesse oferecer uma vaga de trabalho em empresa privada e conseqüentemente melhorar as condições do cumprimento da pena.

No ano 2000, período em que o Dr. Sebastião Coelho da Silva esteve como Juiz Titular da Vara de Execuções Criminais, o trabalho externo em empresas privadas foi efetivando, como alternativa para o trabalho no regime semi-aberto, proporcionando a parceria entre a Execução Penal e a Sociedade Civil, na reinserção do preso na sociedade.

Os presos com deferimento para Trabalho Externo e o Termo de Consentimento assinado pelo empregador (Ver anexo 7), após reunião de triagem e

\footnotetext{
${ }^{6}$ Os motivos positivos são o término da pena ou obtenção de outro lugar para trabalhar e os
} motivos negativos podem ser analisados detalhadamente no Anexo 2 deste trabalho. 
esclarecimento das regras do benefício, na Seção Psicossocial da Vara de Execuções Criminais tem prioridade de transferência de estabelecimento prisional, para facilitar a locomoção para o local de trabalho.

Os sentenciados são transferidos do Complexo Penitenciário, localizado na região perto da cidade satélite de São Sebastião, para o Centro de Progressão Penitenciária - CPP, localizado no Setor de Indústrias e Abastecimento - SIA, trecho 4. Este estabelecimento tem capacidade para aproximadamente 350 homens, mas em abril de 2007 acomodava 448 internos.

O objetivo deste presídio, que possui regras mais brandas, melhor estrutura física e condições de cumprimento da pena, era abrigar todos os sentenciados que progrediam de regime. Mas diante da falta de vagas, definiu-se que os presos que já possuem o termo assinado terão prioridade, para evitar que eles percam a vaga de trabalho.

\subsection{Os profissionais que lidam com a concessão do benefício}

Os sentenciados que recebem o deferimento da progressão de regime têm os seus nomes repassados para a FUNAP, que se responsabiliza de encaminhá-los para os postos de trabalho, na medida em que as vagas vão surgindo. Por isso, os familiares que não tiverem meios de oferecer uma proposta de emprego em empresa privada, não prejudicam o processo do seu ente, somente agilizam um processo que aconteceria de forma natural.

A oficialização da vaga de trabalho se dá por meio de uma carta, onde deve constar os dados da empresa, como nome, telefone, endereço e nome do responsável legal, a descrição da função que o sentenciado irá desenvolver, bem como horários e salário.

O desenvolvimento do Trabalho Externo é de responsabilidade de três áreas profissionais distintas: os profissionais da SEVEC que realizam os contatos iniciais com os empregadores, a Assessoria do Juiz e o próprio Magistrado que são responsáveis pelo deferimento do pedido e pela equipe de fiscalização do CPP.

A proposta deve ser entregue no cartório da VEC. Anexada ao processo, ambos são encaminhados à Seção Psicossocial da Vara de Execuções Criminais, para serem analisados, a atividade que será desempenhada e a ligação com o delito também são verificados. Posteriormente, o empregador é convocado via telegrama ou telefonema, 
para comparecer à referida Seção, portando os documentos da empresa: CNPJ, Estatuto Social, Alvará de Funcionamento e Documentos Pessoais.

A documentação é verificada e posteriormente as regras do benéfico são esclarecidas. A finalidade da reunião é deixar claro certos pontos que podem gerar dúvida no cumprimento do benéfico e acarretar em punição ou até mesmo na perda da autorização para trabalhar.

O benefício que o sentenciado recebe é somente para trabalhar. Aqueles que não possuem autorização para desempenhar atividades fora da empresa, não podem se ausentar. As refeições devem ser feitas no restaurante mais próximo ou realizadas dentro da própria empresa. Os horários são rigorosos; o sentenciado tem uma hora para se deslocar do local de trabalho para o presídio e vice-versa.

Outra discussão que permeia as atividades dos profissionais desta Seção é a capacidade específica para a triagem dos documentos e algumas particularidades sobre legislação trabalhista e direito. A SEVEC é composta por Assistentes Sociais, Psicólogos e Pedagogos, que durante a sua formação profissional são preparados para tais especificidades.

Por isso, o debate se tais atividades são mesmo atribuições destes profissionais e até mesmo se a SEVEC é a Seção que deve ser responsável por tal demanda. A preocupação levantada não tem o objetivo de questionar a capacidade profissional destas pessoas, mas sim, a especificidade destas atividades e a importância que a eles vem sendo dada.

Após a reunião, um profissional da SEVEC fica responsável por relatar o procedimento adotado, bem como a documentação que foi apresentada pelo empregador e se desejar, a sua posição profissional quanto à concessão do benéfico. Ultimamente, estes profissionais não têm dado um parecer final sobre os processos que analisam, pois não há uma definição clara sobre os critérios que devem ser adotados.

Posteriormente, o processo, juntamente com a carta de proposta e agora, o relatório da SEVEC são encaminhados ao Juiz responsável que julgará sobre o deferimento do pedido. A legislação que pauta esta decisão é a Lei de Execução Penal, em seus artigos 28, 29, 36 e 37 (Ver Anexos 1). Não existe lei complementar, decreto ou portaria que sistematize os critérios adotados para o deferimento dos pedidos. Tal falha da justiça faz com que muitas vezes, o bom senso e as subjetividades dos profissionais que atuam diretamente na concessão do benefício, prevaleçam em face aos direitos coletivos. 
Por isso, algumas vezes, atividades profissionais como office-boy, entregador de pizza, cobrador de transporte alternativo, dentre outras, foram deferidas pelo Juiz responsável, mesmo com parecer negativo da SEVEC, pela falta de critérios objetivos e universais para deferimento dos pedidos de Trabalho Externo.

Quando o sentenciado já possui autorização para o trabalho, os Policiais Civis e Agentes Penitenciários do Centro de Progressão Penitenciária são responsáveis por visitar os estabelecimentos, com o objetivo de verificar se o preso está cumprindo suas responsabilidades de acordo com o Termo de Compromisso assinado pelo empregador, além de averiguar possíveis denúncias ou suspeitas.

Aqueles que não se encontram no local previamente estipulado são punidos e podem até perder o beneficio. No momento da visita, o sentenciado deve estar na empresa e nas mediações próximas, mesmo que seja em horário de almoço, início ou término do expediente.

Ao analisarmos a estrutura dos profissionais que atuam diretamente sobre o Trabalho Externo notamos que não existe acompanhamento aos empregadores e nem mesmo aos sentenciados. A equipe da SEVEC conta com duas funcionárias e eventualmente outras são destinadas para essa área, para atender toda a demanda de propostas apresentadas no Distrito Federal.

Diante do aumento do número de processos a serem analisados e da insuficiência de profissionais, o acompanhamento do trabalho, do comportamento do sentenciado e o auxílio ao empregador não está sendo realizado. A SEVEC analisa e relata, o Juiz defere e a equipe do CPP, fiscaliza. Quando existe alguma eventualidade ou alteração no comportamento do preso, a solução mais fácil de ser tomada é a demissão.

A falta de acompanhamento não é causada por ausência de interesse profissional das partes citadas anteriormente. Mas principalmente, pela insuficiência de recursos humanos e de critérios objetivos que sirvam como base para as tomadas de decisão sobre o Trabalho Externo, tornando os critérios coletivos e universais e não como vem ocorrendo, subjetivos e pessoais.

\section{3 $O$ perfil das empresas}

Com a finalidade de se traçar um perfil das instituições que se dispõem a oferecer vagas de trabalho aos sentenciados do regime semi-aberto, foi realizada uma 
pesquisa sobre o ramo que essas empresas atuam, as funções que os sentenciados desempenham nas instituições e os motivos que levaram o empregador a oferecer a proposta.

Os dados foram obtidos a partir da análise dos relatórios elaborados pela SEVEC nos anos de 2005 e 2006. Que mostrou, dentre outras coisas, que o aumento de processos de um ano para outro foi significativa: em 2005 foram analisados 244 processos e no ano seguinte, 376, representando um aumento de $54 \%$ da demanda e a mesma quantidade de profissionais.

O motivo deste aumento de demanda é causado em parte, pela ampliação da divulgação do benefício. Antes que o sentenciado receba a autorização do Juiz para passar os finais de semana em casa, outro benefício do regime semi-aberto, as famílias dos sentenciados são recebidas pelos profissionais da SEVEC.

$\mathrm{Na}$ ocasião da entrevista, muitas famílias foram orientadas que além da FUNAP, seus entes poderiam trabalhar em empresas privadas, desde que a proposta fosse idônea. Diante desta informação, as famílias começaram a se articular para providenciar esta oportunidade de trabalho. Caso essa informação não seja fornecida durante o atendimento familiar, seria mais difícil entender a importância dessa vaga de trabalho e os meios de como conseguir a sua tramitação.

A pesquisa se ateve às propostas analisadas. Casos de devolução de processo, relatório informativo, certidões e outros casos não foram contemplados nestes números, pois o objetivo era analisar as propostas que resultavam em pareceres para o Juiz da Execução Penal. Em 2005 foram aproximadamente 40 processos devolvidos e em 2006, 56 processos. A maior causa foi a falta de endereço e telefone que inviabiliza o acesso aos empregadores.

Quanto às empresas que oferecem essas vagas, observamos que elas apresentam um perfil muito similar. Em geral são micro-empresas ${ }^{7}$, onde o sentenciado desenvolve atividades que exigem pouca escolaridade e especialização, sem proteção social e previdenciária, porque o trabalho do sentenciado não é regido pela Consolidação das Leis Trabalhistas - CLT e sim pela Lei de Execução Penal - LEP. Na maioria dos

\footnotetext{
${ }^{7} \mathrm{O}$ decreto $\mathrm{n}^{\circ} 5.028 / 2004$ definiu que micro-empresas são aquelas que a receita bruta anual é igual ou inferior a $\mathrm{R} \$ 433.755,14$. O regime simplificado de tributação SIMPLES, que considera estritamente a parte tributária das organizações, adota o critério da Medida Provisória 275/05 que define micro - empresa como aquele que possui receita bruta anual igual ou inferior a R \$240.000. Além destes critérios, o SEBRAE conceitua que este ramo empresarial possui até 19 pessoas trabalhadoras, no caso da indústria e construção civil e 9 trabalhadores no caso do comércio e serviços.
} 
casos, o empregador já possuía algum tipo de relação como sentenciado antes do recolhimento prisional, como empregador ou como amigo da família.

Tabela 1 : Ramo das empresas

Ano: 2005

\begin{tabular}{|c|c|c|c|c|c|c|c|c|c|c|c|c|}
\hline & $\begin{array}{l}0 \\
\text { ज̃ } \\
0 \\
0 \\
0 \\
0 \\
0 \\
0 \\
0 \\
0 \\
z\end{array}$ & 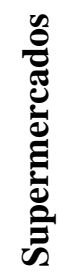 & 葛 & 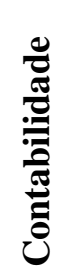 & ن & 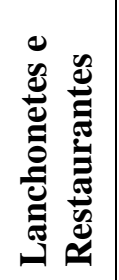 & 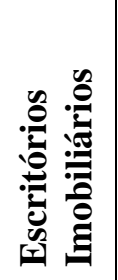 & 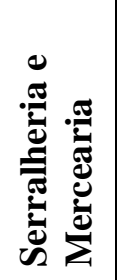 & 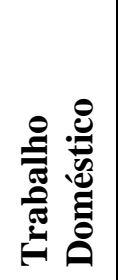 & 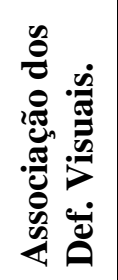 & 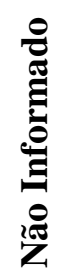 & 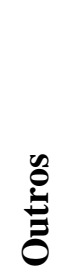 \\
\hline Janeiro & 8 & & 1 & & & 2 & & 3 & & 1 & & 1 \\
\hline Fevereiro & 5 & 1 & & & & & 1 & & & & 1 & 2 \\
\hline Março & 15 & 3 & 2 & & 1 & & & & & & 1 & 8 \\
\hline Abril & 23 & & 2 & & 4 & & & & & & 2 & 15 \\
\hline Maio & 10 & & 3 & & 1 & & & & & & & 6 \\
\hline Junho & 16 & & 1 & & 2 & & & & 2 & & 1 & 10 \\
\hline Julho & 19 & 2 & 1 & & 1 & & & & 1 & 1 & 1 & 12 \\
\hline Agosto & 44 & 2 & 7 & & 2 & & 2 & & 2 & 3 & 3 & 23 \\
\hline Setembro & 19 & & 6 & & & & & & & & 5 & 8 \\
\hline Outubro & 32 & 7 & 5 & 1 & 3 & & & & & & 2 & 14 \\
\hline Novembro & 25 & 2 & 5 & 1 & 1 & & 2 & & & & 2 & 12 \\
\hline Dezembro & 28 & 2 & 4 & & 3 & 1 & 1 & & & & 4 & 13 \\
\hline Total & 244 & 19 & 37 & 2 & 18 & 3 & 6 & 3 & 5 & 5 & 22 & 124 \\
\hline
\end{tabular}

Fonte: Elaboração Própria, 2007.

As oficinas mecânicas é o ramo que mais emprega os sentenciados. Seguido pelos supermercados e pela construção civil. Um setor que apareceu em destaque foi uma associação de deficientes visuais, que no ano de 2005 apresentou 5 propostas de emprego. Esta empresa trabalha com confecção de roupas e foi criada especialmente para atender aos sentenciados que necessitam se inserir no mercado de trabalho.

Dentro da categoria de outras atividades, podemos destacar lojas de informática, gráficas, academias, agências de turismo, postos de gasolina, salões de beleza, farmácias, igrejas evangélicas e católicas e até uma rede de televisão que ofereceu uma proposta.

Em 2005 não constava nenhum proposta de empresa de pequeno, médio ou grande porte, nem mesmo em as empresa do ramo da construção civil, todas estavam enquadradas na concepção de micro-empresa. 
Em 2006 notamos que esse perfil do ramo das empresas não se alterou muito:

Tabela 2 : Ramo da Empresa

Ano: 2006

\begin{tabular}{|c|c|c|c|c|c|c|c|c|c|c|c|c|}
\hline & 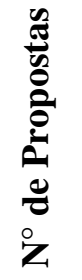 & 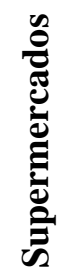 & 苞 & 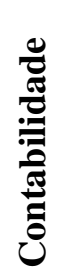 & ن & 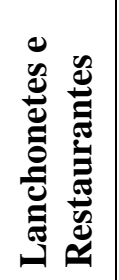 & 串 & 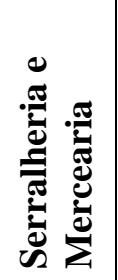 & 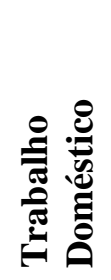 & 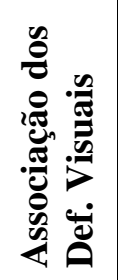 & 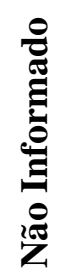 & $\stackrel{n}{\stackrel{0}{0}}$ \\
\hline Janeiro & 14 & 2 & 1 & 1 & 1 & 2 & 1 & & 1 & & 0 & 5 \\
\hline Fevereiro & 8 & & & & & & & & & & 7 & 1 \\
\hline Março & 22 & 1 & 4 & & 2 & 1 & & & 1 & 2 & 5 & 6 \\
\hline Abril & 13 & 1 & & & 1 & 1 & 2 & 2 & & & & 7 \\
\hline Maio & 40 & 4 & 6 & 3 & 2 & 4 & & & & 1 & 5 & 15 \\
\hline Junho & 36 & 3 & 5 & 1 & 2 & 3 & & 1 & 2 & 1 & 4 & 14 \\
\hline Julho & 35 & 3 & 4 & & & 2 & & & 1 & 3 & 3 & 19 \\
\hline Agosto & 44 & & 8 & 4 & & 1 & 2 & & 2 & & 2 & 25 \\
\hline Setembro & 54 & 4 & 7 & 3 & 5 & 1 & 1 & 7 & 1 & & & 25 \\
\hline Outubro & 40 & 5 & 5 & 2 & 2 & 2 & & 5 & 3 & 2 & & 14 \\
\hline Novembro & 38 & 7 & 3 & 1 & 1 & 1 & & 1 & & & & 24 \\
\hline Dezembro & 32 & 2 & 9 & 2 & 2 & 1 & 1 & & & & & 15 \\
\hline Total & 376 & 32 & 52 & 17 & 18 & 19 & 7 & 15 & 11 & 9 & 26 & 170 \\
\hline
\end{tabular}

Fonte: Elaboração Própria, 2007.

As oficinas mecânicas continuam sendo o principal ramo empregador, com um aumento considerável de propostas oferecidas. Seguida pelos supermercados, construção civil e empresas de alimentação. A associação de deficientes visuais também aumentou o seu número de propostas.

Nos dois anos, o perfil das propostas é formado basicamente de microempresas. Elas não recebem incentivos fiscais, isenção de impostos, e nem incentivos sociais, como reconhecimento do serviço que prestam para a sociedade. A única vantagem é que as custas salariais do trabalhador sentenciado é mais baixa, porque por lei, ele não tem direito aos direitos trabalhistas da CLT. 
Esses sujeitos trabalham em atividades que exigem pouca qualificação profissional e escolaridade. A maioria como auxiliar de serviços gerais e auxiliar administrativo.

Tabela 3 : Atividades desenvolvidas

Ano: 2005

\begin{tabular}{|c|c|c|c|c|c|c|c|c|c|c|c|}
\hline & 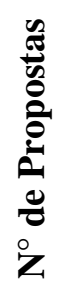 & 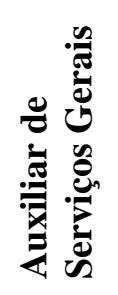 & 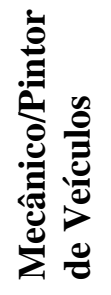 & 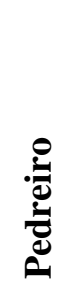 & 总 & 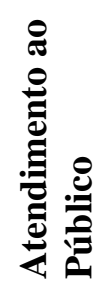 & 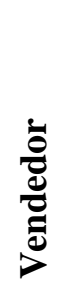 & 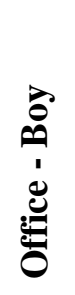 & 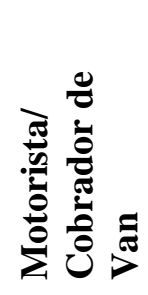 & 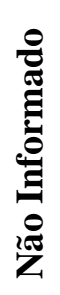 & 号 \\
\hline Janeiro & 8 & 3 & 1 & & & & & 1 & & & 3 \\
\hline Fevereiro & 5 & & & & 2 & 1 & & & & & 2 \\
\hline Março & 15 & 4 & 2 & 1 & & 1 & & 1 & & 1 & 5 \\
\hline Abril & 23 & 3 & 1 & 4 & 2 & 1 & 2 & 3 & 2 & & 5 \\
\hline Maio & 10 & 2 & 2 & 1 & & & 2 & & & & 3 \\
\hline Junho & 16 & 2 & & 1 & & 3 & 1 & 1 & & & 8 \\
\hline Julho & 19 & 2 & 1 & & 3 & 1 & 3 & 2 & 2 & & 5 \\
\hline Agosto & 44 & 12 & 4 & 1 & 7 & 2 & 2 & 2 & 1 & 1 & 12 \\
\hline Setembro & 19 & 3 & 4 & & 1 & & 1 & 3 & 1 & & 6 \\
\hline Outubro & 32 & 3 & 4 & 2 & 3 & 4 & & 1 & 6 & & 9 \\
\hline Novembro & 25 & 1 & 4 & 1 & 3 & & 3 & 2 & 5 & 1 & 8 \\
\hline Dezembro & 28 & 4 & 3 & 2 & 1 & 1 & 3 & & 1 & & 13 \\
\hline Total & 244 & 39 & 26 & 13 & 22 & 14 & 17 & 16 & 15 & 3 & 79 \\
\hline
\end{tabular}

Na categoria de outros, temos alguns casos que exigiam mão de obra qualificada como conserto de antenas, conserto de eletroeletrônicos e estagiário de Comunicação Social. Durante o ano de 2005, propostas de atividades externas, como office-boy, motorista e cobrador de van eram aceitas e por isso, analisadas.

Em 2006 essas atividades externas nem constavam na tabela, por isso as famílias e os profissionais da SEVEC foram orientados que a possibilidade de indeferimento seria grande, devido à dificuldade de fiscalização.

Na categoria “outros”, temos uma proposta de trabalho de assessor jurídico e outras duas para estagiários. E outras atividades que exigem maior capacitação, como 
decoração com balões. Nos demais processos, as atividades não exigem qualificação por parte do trabalhador, o que representa baixa remuneração.

Tabela 4: Atividades desenvolvidas

Ano: 2006

\begin{tabular}{|c|c|c|c|c|c|c|c|c|}
\hline & 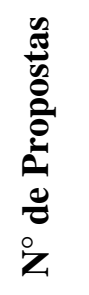 & 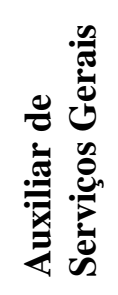 & 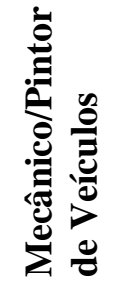 & مُّة & 逽 & 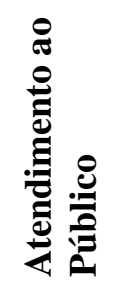 & $\frac{\partial}{0}$ & 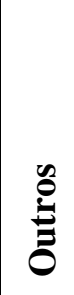 \\
\hline Janeiro & 14 & 2 & 1 & 1 & 1 & 3 & 1 & 5 \\
\hline Fevereiro & 8 & 3 & 1 & & 2 & & & 2 \\
\hline Março & 22 & 4 & 4 & 2 & 1 & 2 & & 9 \\
\hline Abril & 13 & 2 & & 1 & 4 & 1 & & 5 \\
\hline Maio & 40 & 5 & 5 & & 8 & 3 & 3 & 16 \\
\hline Junho & 36 & 7 & 6 & 1 & 4 & & 4 & 14 \\
\hline Julho & 35 & 11 & 1 & & 4 & 2 & 1 & 16 \\
\hline Agosto & 44 & 12 & 4 & 1 & 6 & 3 & 1 & 17 \\
\hline Setembro & 54 & 12 & 3 & 5 & 5 & 3 & 6 & 20 \\
\hline Outubro & 40 & 3 & 4 & & 4 & 1 & & 28 \\
\hline Novembro & 38 & 9 & 2 & 1 & 1 & 2 & 3 & 20 \\
\hline Dezembro & 32 & 6 & 6 & 2 & 4 & 3 & 6 & 5 \\
\hline Total & 376 & 76 & 37 & 14 & 44 & 23 & 25 & 157 \\
\hline
\end{tabular}

Fonte: Elaboração Própria, 2007.

Observamos que a relação entre o empregador e o sentenciado não mudou no decorrer dos anos. Como é a família que precisa entrar em contato com o empregador para oferecer a proposta de trabalho, a maioria dos processos apresenta um vínculo de amizade entre o empregador e a família, como principal fator a disponibilização de vaga.

São pessoas que acompanharam o crescimento e o desenvolvimento do sentenciado, que não se conformam com o ingresso na criminalidade e encontram na vaga de trabalho uma oportunidade de ajudar o indivíduo e a sua família.

Acreditam que o sentenciado é inocente e que o seu envolvimento com o delito foi motivado pelo envolvimento com más companhias ou falta de oportunidade, por isso acreditam que o trabalho será fundamental para o indivíduo “sair dessa”. 
Outra situação comum são os empregadores que resolvem readmitir o funcionário, mesmo depois do recolhimento prisional. Alegando que antes da pena, eram bons funcionários e por isso, acreditam que o delito não interfere no seu desenvolvimento profissional e na sua credibilidade.

Tabela 5: Relação Empregador - Sentenciado

Ano: 2005

\begin{tabular}{|c|c|c|c|c|c|c|c|}
\hline & 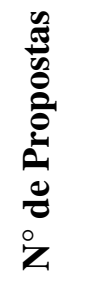 & 丞 & 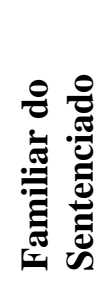 & 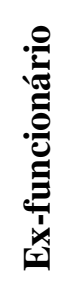 & 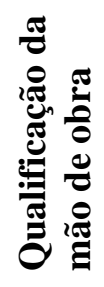 & 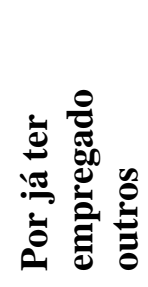 & $\stackrel{8}{0}$ \\
\hline Janeiro & 8 & 6 & 1 & 1 & & & \\
\hline Fevereiro & 5 & & & 1 & & & 4 \\
\hline Março & 15 & 4 & 1 & 6 & & 2 & 2 \\
\hline Abril & 23 & 9 & 6 & 2 & & 1 & 5 \\
\hline Maio & 10 & 2 & & 7 & & & 1 \\
\hline Junho & 16 & 4 & 4 & 6 & & & 2 \\
\hline $\begin{array}{l}\text { Julho } \\
\end{array}$ & 19 & 7 & & 6 & & & 6 \\
\hline Agosto & 44 & 23 & 4 & 9 & 3 & & 5 \\
\hline Setembro & 19 & 3 & 2 & 4 & & & 10 \\
\hline Outubro & 32 & 13 & 4 & 8 & & 1 & 6 \\
\hline Novembro & 25 & 5 & 7 & 9 & & & 4 \\
\hline Dezembro & 28 & 7 & 6 & 7 & & & 8 \\
\hline Total & 244 & 83 & 35 & 66 & 3 & 4 & 53 \\
\hline
\end{tabular}

Fonte: Elaboração Própria, 2007

A tabela acima revela que no ano de 2005, das 244 propostas analisadas, 66 foram oferecidas porque o sentenciado já havia trabalhado na empresa, o que representa $27 \%$ do total. A maior porcentagem, 34\% do total é referente às propostas oferecidas por amigos da família. As oferecidas pela qualificação específica da mão de obra do sentenciado, representam 1,22\% do total, o que reforça a idéia apresentada durante todo o trabalho de que a falta de qualificação profissional do sentenciado é uma das grandes barreiras para a sua (re)inserção no mercado de trabalho.

Em 2006 observamos que esse quadro sofreu algumas alterações. A porcentagem dos que recebem a proposta porque são ex-funcionários dessas empresas, 
praticamente não sofreu mudanças, pois passou de 27\% (em 2005) para 26,59\% em 2006.

Um estrato que sofreu aumento considerável foi o que se refere às propostas de amigos da família, que passou de 34\% em 2005 para 47,60\% em 2006, totalizando 179 propostas. Demonstrando que para aqueles que possuem algum vínculo familiar ou afetivo com os sentenciados, fica mais fácil oferecer a proposta de trabalho.

O segmento que permaneceu praticamente inalterado refere-se às propostas pela qualificação da mão de obra dos sentenciados, que em 2006 representou 1,86\%. È importante salientar, que algumas propostas onde o sentenciado iria trabalhar diretamente com os genitores ou próximo à sua residência, eram indeferidas, porque os profissionais entendiam que o trabalho não poderia ser confundido com as relações familiares.

Relação- Empregador e Sentenciado

Ano: 2006

\begin{tabular}{|c|c|c|c|c|c|c|c|}
\hline & 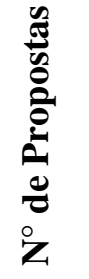 & 疍 & 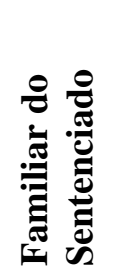 & 麁 & 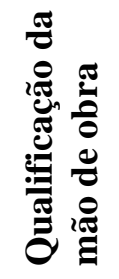 & 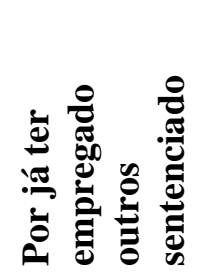 & $\stackrel{n}{0}$ \\
\hline Janeiro & 14 & 8 & 2 & 2 & & & 2 \\
\hline Fevereiro & 8 & 1 & 2 & & & & 5 \\
\hline Março & 22 & 7 & 3 & 6 & & 1 & 5 \\
\hline Abril & 13 & 3 & 1 & 5 & & 1 & 3 \\
\hline Maio & 40 & 17 & 9 & 11 & & & 3 \\
\hline Junho & 36 & 16 & 10 & 10 & & & \\
\hline \begin{tabular}{|l} 
Julho \\
\end{tabular} & 35 & 25 & 1 & 5 & 2 & 2 & \\
\hline Agosto & 44 & 26 & 6 & 7 & 3 & 2 & \\
\hline Setembro & 54 & 24 & 14 & 14 & 1 & & 1 \\
\hline Outubro & 40 & 17 & 5 & 15 & 1 & 2 & \\
\hline Novembro & 38 & 22 & 5 & 10 & & 1 & \\
\hline Dezembro & 32 & 13 & 3 & 15 & & 1 & \\
\hline Total & 376 & 179 & 61 & 100 & 7 & 10 & 19 \\
\hline
\end{tabular}

Fonte: Elaboração Própria, 2007 


\section{Análise das entrevistas}

Com a finalidade de melhor compreender como o Trabalho Externo dos presos vem se efetivando no Distrito Federal, realizamos entrevistas com três grupos de atores envolvidos com a questão do trabalho externo: os sentenciados, os empregadores e os profissionais da SEVEC que lidam com esse aspecto da execução penal. As perguntas focaram principalmente a natureza da proposta, os direitos dos presos e o processo de (re) inserção social pelo trabalho.

As entrevistas foram realizadas no período de abril a maio de 2007. As respostas foram gravadas e posteriormente transcritas, juntamente com os comentários dos entrevistados. Todos os entrevistados foram esclarecidos dos objetivos da pesquisa e assinaram o Termo de Consentimento, cujo modelo se encontra no Anexo 3 deste trabalho. Ao término do processo de análise/ transcrição obtivemos 18 páginas como resultado.

O objetivo inicial era buscar empresas que representassem os maiores segmentos empregadores de 2005 e 2006, que no caso seriam as Oficinas Mecânicas, a Construção Civil e os Supermercados. Incluímos a Associação de Deficientes Visuais do DF, por ser a única entidade sem fins lucrativos que emprega sentenciados egressos, desempenhando um papel de ressocialização de destaque.

Dos relatórios que se encontravam arquivados na SEVEC após análise das propostas, poucos dispunham do endereço e telefone da empresa, o que tornou difícil o acesso aos empregadores. Optamos portanto, pela amostragem aleatória, determinada pela possibilidade de acesso, no período da pesquisa, (fevereiro a abril de 2007).

No total, foram realizadas nove entrevistas: cinco com sentenciados, duas com empregadores e duas com profissionais da SEVEC. Quatro empresas foram visitadas: uma gráfica, onde empregador e sentenciado foram entrevistados, uma empresa de refrigeração, onde o empregador foi entrevistado, mas o sentenciado não compareceu ao trabalho no dia, um supermercado onde o sentenciado foi entrevistado e o empregador não quis falar sobre o assunto e a Associação dos Deficientes Visuais, onde três presos foram entrevistados e a empregadora não pode nos atender por motivos de saúde na família. 


\subsection{Entrevista dos sentenciados}

Com o objetivo de melhor mostrar os dados obtidos por meio das entrevistas, foi elaborada uma tabela com as informações, traçando um perfil sobre a idade, escolaridade, trabalhos anteriores, cursos realizados, estado civil e número de filhos dos sentenciados entrevistados.

Os presos foram numerados para manter o sigilo de suas identidades:

\begin{tabular}{|c|c|c|c|c|c|}
\hline & PRESO 1 & PRESO 2 & PRESO 3 & PRESO 4 & PRESO 5 \\
\hline Idade & 27 anos & 28 anos & 40 anos & 22 anos & 35 anos \\
\hline Escolaridade & $\begin{array}{l}5^{\circ} \text { Série } \\
\text { Ensino } \\
\text { Fundamental }\end{array}$ & $\begin{array}{l}5^{\circ} \text { Série } \\
\text { Ensino } \\
\text { Fundamental }\end{array}$ & $\begin{array}{l}\text { Ensino } \\
\text { Fundamental } \\
\text { Completo }\end{array}$ & $\begin{array}{l}5^{\circ} \text { Série } \\
\text { Ensino } \\
\text { Fundamental }\end{array}$ & $\begin{array}{l}\text { Ensino Médio } \\
\text { Completo }\end{array}$ \\
\hline $\begin{array}{l}\text { Trabalhos } \\
\text { Anteriores }\end{array}$ & $\begin{array}{l}\text { Agência } \\
\text { de carros }\end{array}$ & Letreiro & $\begin{array}{l}\text { Montagem e } \\
\text { Reforma de } \\
\text { imóveis }\end{array}$ & Bicos & Bicos \\
\hline Cursos & $\begin{array}{l}\text { Informática } \\
\text { Básica - FUNAP }\end{array}$ & Nenhum & $\begin{array}{l}\text { Alfaiate } \\
\text { e Serígrafo- } \\
\text { FUNAP }\end{array}$ & Nenhum & $\begin{array}{l}\text { Informática } \\
\text { e Confecção } \\
\text { de bolas- } \\
\text { FUNAP }\end{array}$ \\
\hline Estado Civil & Solteiro & Solteiro & Viúvo & Solteiro & Solteiro \\
\hline Filhos & 2 & 2 & 5 & Nenhum & 2 \\
\hline $\begin{array}{l}\text { Tempo que está } \\
\text { na empresa }\end{array}$ & 4 meses & 5 meses & 8 meses & 1 mês & 5 meses \\
\hline $\begin{array}{ll}\text { Ramos da } \\
\text { Empresa }\end{array}$ & Supermercado & $\begin{array}{l}\text { Galpão de } \\
\text { Confecção } \\
\text { de roupas }\end{array}$ & $\begin{array}{l}\text { Galpão de } \\
\text { Confecção } \\
\text { de roupas }\end{array}$ & Gráfica & $\begin{array}{ll}\text { Galpão } & \text { de } \\
\text { Confecção } & \text { de } \\
\text { roupas } & \end{array}$ \\
\hline Salário & $\begin{array}{ll}\text { Não } & \text { está } \\
\text { recebendo } & \end{array}$ & $\begin{array}{l}\mathrm{R} \$ 600,00 \text { - } \\
\text { produção }\end{array}$ & $\begin{array}{l}\mathrm{R} \$ 500,00 \text { - } \\
\text { produção }\end{array}$ & $\begin{array}{l}\mathrm{R} \$ 600,00- \\
\text { fixo }\end{array}$ & $\mathrm{R} \$ 400,00$ \\
\hline
\end{tabular}




\begin{tabular}{|c|c|c|c|c|c|}
\hline $\begin{array}{l}\text { Benefícios } \\
\text { recebidos }\end{array}$ & Nenhum & Nenhum & Nenhum & $\begin{array}{ll}\text { Todos } & \text { os } \\
\text { direitos } & \text { da } \\
\text { CLT } & \end{array}$ & Nenhum \\
\hline $\begin{array}{l}\text { Horário de } \\
\text { Trabalho }\end{array}$ & $8 \mathrm{~h}$ às $16 \mathrm{~h}$ & $8 \mathrm{~h}$ às $18 \mathrm{~h}$ & 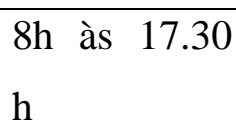 & $8 \mathrm{~h}$ às $18 \mathrm{~h}$ & $8 \mathrm{~h}$ às $17 \mathrm{~h}$ \\
\hline $\begin{array}{ll}\text { Quantidade } & \text { de } \\
\text { funcionários } & \text { da } \\
\text { empresa } & \end{array}$ & 5 & 4 & 4 & 6 & 4 \\
\hline $\begin{array}{l}\text { Empregados na } \\
\text { condição de semi- } \\
\text { aberto }\end{array}$ & 1 & 3 & 3 & 1 & 3 \\
\hline $\begin{array}{l}\text { Vínculo com o } \\
\text { empregador }\end{array}$ & $\begin{array}{l}\text { Amigo da } \\
\text { família }\end{array}$ & $\begin{array}{l}\text { Amigo da } \\
\text { família }\end{array}$ & $\begin{array}{l}\text { Indicado por } \\
\text { outro preso }\end{array}$ & $\begin{array}{l}\text { Ex- } \\
\text { funcionário }\end{array}$ & $\begin{array}{l}\text { Amigo da } \\
\text { família }\end{array}$ \\
\hline $\begin{array}{l}\text { Função que } \\
\text { exerce }\end{array}$ & Serviços Gerais & $\begin{array}{l}\text { Confecção } \\
\text { de roupas }\end{array}$ & $\begin{array}{l}\text { Confecção } \\
\text { de roupas }\end{array}$ & $\begin{array}{l}\text { Operador de } \\
\text { máquina } \\
\text { gráfica }\end{array}$ & $\begin{array}{l}\text { Confecção de } \\
\text { roupas }\end{array}$ \\
\hline
\end{tabular}

Elaboração Própria, 2007.

Ao analisarmos o quadro acima, notamos que o perfil dos sentenciados entrevistados não difere do restante dos internos do sistema carcerário do DF. A idade média de 30.4 anos, baixa escolaridade e pouca qualificação profissional. Aqueles que informaram que já fizeram algum tipo de cursos, foram qualificados dentro do sistema prisional pela FUNAP.

Antes do recolhimento, estavam inseridos no mercado de trabalho informal. Alguns com atividades esporádicas (bicos) e salário proporcional à produção, sem fixo e nem direitos trabalhistas, como carteira assinada, $13^{\circ}$ salário, férias e recolhimento previdenciário.

Na situação de sentenciado em regime semi-aberto, o trabalho é visto como um privilégio, diante da escassez de vagas na esfera pública e privada. Por isso, quando o sentenciado começa a trabalhar, ele não apresenta preocupação de exigir os seus direitos. Quando indagado sobre o assunto, um dos sentenciados respondeu: 
“Também não tenho conhecimento não. Acho que preso não tem nenhum direito como trabalhador e mesmo se tivesse algum, não correria atrás, essa vaga de emprego já é muita coisa, já está de bom tamanho”. Preso 1

A lei é clara quando diz que o sentenciado que desenvolve atividades laborais deverá ser regido pela LEP, portanto, não usufruem de direitos trabalhistas como os empregados regidos pela CLT. Mas os empregadores têm sido orientados pela SEVEC para recolherem o INSS de seus funcionários.

Durante as entrevistas, notou-se que a empregadora dos Presos 2, 3 e 5 não paga os devidos benefícios aos seus funcionários - presos, por falta de condições e não de vontade própria, segundo o depoimento dos entrevistados.

A empresa foi criada com a finalidade de ajudar na reinserção social dos presos egressos, todas as máquinas e material foram adquiridos com recursos próprios da empregadora. Os presos trabalham e toda a produção é para o seu sustento. Por isso a empregadora não tem condição de garantir os direitos trabalhistas dos seus funcionários, nem mesmo a alimentação e o vale-transporte, o que não deixa de revelar a precarização do trabalho a que esses presos trabalhadores estão expostos.

Sobre discriminação e preconceito no local de trabalho obtivemos as seguintes declarações:

\footnotetext{
"Houve um caso de uma mulher que discriminou a gente. Mas hoje isso já mudou e ela até ajuda a gente. Pessoas que eu achava que iriam discriminar a gente nos tratam muito bem, o que é a maioria”. Preso 5

"Não. Embora a empregadora faça questão de não esconder de ninguém que a maioria lá ainda está cumprindo pena”. Preso 2
}

De acordo com a fala dos sentenciados, o direito de tratamento igualitário está sendo garantido. E esse é mais difícil de ser efetivado do que qualquer direito trabalhista que as legislações possam estabelecer. O que esses sujeitos precisam é de serem tratados como seres humanos, terem as mesmas oportunidades que as demais pessoas e conseguirem meios de diminuir as seqüelas dos anos de recolhimento.

O trabalho para a pessoa presa é um meio de garantir o custeio das necessidades, como é para toda a sociedade. Ao recolocar o egresso no convívio social e no ambiente profissional, a sociedade responde como está vendo este sentenciado, após os anos de encarceramento: 
“Este trabalho é uma experiência que nunca vivi antes. Antes eu achava que seria discriminado ao sair do presídio, mas o trabalho está me mostrando que não é assim sempre. Aqui todos são tratados como irmãos. O dinheiro que recebo ajuda a manter a bicicleta que gasta muito e no meu próprio sustento". Preso 2

“... foi o meio de voltar para a sociedade aos poucos, ver como ela iria receber a gente e ao mesmo tempo já ir recebendo algum dinheiro e ajudar a manter a minha família”. Preso 5

Nos casos onde o trabalho externo é utilizado como meio de exploração da mão de obra do sentenciado, como ficou evidenciado na entrevista com o Preso 1, pois o sentenciado não recebia salário há meses, a alimentação era realizada no local e o seu empregador não apresentava nenhuma justificativa ou preocupação com as condições do seu trabalho, mesmo assim, o interno informou que o trabalho externo possibilitou -lhe o distanciamento do ambiente prisional, considerado nocivo e estressante:

\footnotetext{
"essa vaga ajudou para eu sair um pouco do ambiente prisional”. Preso 1

"Com certeza. O trabalho melhorou muito a minha vida é melhor do que ficar lá dentro do presídio”. Preso 3
}

\subsection{Entrevista com os empregadores}

No caso dos empregadores, conseguimos analisar duas situações muito distintas: no primeiro caso, o empregador já era patrão do sentenciado antes do recolhimento prisional e no segundo, o dono da empresa ofereceu a proposta a pedido da genitora do preso.

A primeira empresa citada é uma gráfica de pequeno porte, localizada na cidade satélite de Ceilândia-DF. Possui seis funcionários e apenas um na condição de regime semi-aberto. No período da entrevista, o sentenciado estava trabalhando na empresa há aproximadamente um mês, como técnico de gráfica.

A segunda empresa localizada na Asa Norte-DF atua no ramo de refrigeração e ar-condicionado, possui treze funcionários e somente um na condição de preso trabalhador. No período da entrevista o sentenciado estava trabalhando na empresa há aproximadamente cinco meses, como responsável pelo almoxarifado.

Em ambos os casos, a gravidade do delito cometido não interferiu no momento de oferecer a proposta e nem no decorrer do desenvolvimento do trabalho na empresa:

“Como eu disse, sei de tudo, até fui às audiências dele e por isso, sei que ele é inocente. Mas isso não faz diferença nenhuma, no trabalho ele até está um trabalhador melhor, está dando mais valor, está mais tranqüilo e disciplinado”. Empregador 1 
"Não consigo ligar o delito dele com o comportamento que ele tem hoje. Acho que foi o artigo 157 ou 151, mas isso não faz diferença para a gente”. Empregador 2

Os entrevistados revelaram que seus funcionários nunca sofreram nenhum tipo de discriminação ou preconceito, embora em ambas empresas, todos saibam da situação criminal.

Na percepção dos empregadores, o trabalho é visto como fundamental para reinserção social do sujeito, porque possibilita o distanciamento do estabelecimento prisional e porque facilita a relação com outras pessoas e situações da vida.

“O trabalho é muito importante. Se ele não estivesse trabalhando seria muito pior, é bom porque $1^{\circ}$ ele saiu do presídio e $2^{\circ}$ porque ele está exercendo a função dele, a habilidade dele. Essa experiência faz ele dar mais valor ao trabalho”. Empregador 1

"Uns $80 \%$ para a reinserção social é o trabalho. Ele está convivendo com outras pessoas e clientes e é muito bom. E qualquer pessoa, independente de preso, precisa trabalhar, para buscar novos cursos, novas coisas”. Empregador 2

Os entrevistados afirmaram que consideram os sentenciados como cidadãos de direitos. Por isso, lhe asseguram os direitos trabalhistas de um trabalhador comum e salário igualitário ao dos demais funcionários, isso, porque os responsáveis legais pelas empresas, não consideram a perda de direitos trabalhistas como um incentivo fiscal ou social para oferecem trabalho aos sentenciados do regime semi-aberto.

Afirmam ser importante o governo se preocupar em oferecer incentivos às empresas, embora quem faça isso, seja motivado por outros fatores que não são econômicos.

Perda de direitos trabalhistas não é incentivo fiscal. Para se aumentar a quantidade de vagas nas empresas privadas, o empregador deve receber incentivos reais, pois o dever de abrir postos de trabalho é do governo, conforme preconizado. A sociedade civil e o empresariado devem colaborar e auxiliar, em convênios e parcerias formais.

Quando indagados sobre a possibilidade de oferecer a oportunidade de trabalho para outros sentenciados os empregadores responderam:

“De forma alguma! Para eles terem consciência e passarem confiança para a gente é muito difícil. Eu só empreguei o rapaz porque ele já era meu funcionário... ( ) Nem se eu não precisasse pagar nenhum imposto mais eu empregaria outro”. Empregador 1 
"Com certeza. No momento não estamos precisando, mas tenho interesse sim de alguém que tenha especialidade para a área. Independente de conhecer ou não”. Empregador 2

Notamos que os vínculos afetivos ainda prevalecem face à responsabilidade social. No caso do empregador 1 , fica claro que a proposta foi oferecida apenas porque 0 funcionário é considerado inocente do delito condenado.

No caso do empregador 2, sua empresa está aberta para contratar novos funcionários na condição de sentenciados, independente de prévio conhecimento. Mas vale ressaltar que, segundo as normas do benefício, o empregador tem responsabilidade no seu cumprimento. $\mathrm{O}$ trabalho do preso deve seguir rotinas e horários, tanto para chegar ao presídio quanto para sair, além de estarem sujeitos às visitas de fiscalização que podem ocorrer a qualquer momento.

Esta empresa não demonstrou preocupação quanto às suas responsabilidades, já que no dia da entrevista, o sentenciado não compareceu ao trabalho. O horário estipulado previamente com empregadora e sentenciado foi às 8 horas da manhã, mas até as 9 horas o preso não tinha chegado.

A responsável pelo estabelecimento foi informada, por outro funcionário, de que o sentenciado não iria trabalhar porque não tinha sido liberado no presídio. Ela acrescentou, que alguns dias ele sai no horário de trabalho para resolver problemas pessoais do seu casamento que deve ocorrer ainda no mês de maio de 2007. Embora ambos saibam que saídas externas são proibidas.

No período vespertino, entramos em contato com o CPP para averiguar a informação, onde fomos esclarecidos de que o sentenciado foi liberado para trabalhar. Considerar o sentenciado como os demais funcionários da empresa é fundamental para evitar discriminação e preconceito, mas o empregador não pode se eximir das suas responsabilidades por estar empregando uma pessoa que ainda está cumprindo pena.

Pelo discurso da empregadora entrevistada, podemos afirmar que não existe preocupação com as suas responsabilidades e nem com possíveis cobranças da justiça. $\mathrm{O}$ sentenciado tem liberdade para fazer suas atividades corriqueiramente e a fiscalização não tem sido freqüente a ponto de evitar essas situações-problema. 


\title{
5.3 Entrevista com os profissionais
}

O trabalho dos profissionais da SEVEC é de grande relevância para evitar que casos como o citado anteriormente, sejam freqüentes. Além de entrar em contato com os responsáveis pela empresa e fazer a triagem documental, a principal função destes profissionais é orientar e esclarecer sobre as regras do Trabalho Externo.

A equipe específica para essa tarefa é composta por duas profissionais, sendo uma Psicóloga e outra Assistente Social. Quando a demanda é elevada, outros profissionais são direcionados para fazer visitas ou ajudar na triagem nos dias de reuniões com os empregadores.

Durante as entrevistas, somente este grupo de atores demonstrou preocupação de que as propostas de trabalho podem estar servindo apenas para facilitar a transferência do complexo penitenciário para o CPP.

\begin{abstract}
"As propostas têm servido mais para as pessoas saírem do complexo, menos aqueles já são ex-funcionários da empresa. Existem muitos casos que o trabalho serve somente para agilizar a transferência. Inclusive, eu peguei um processo que a família confessou que iria pagar todos os encargos trabalhistas, como salário, vale-transporte e alimentação, o empregador só ajudou com o nome da empresa, tudo isso para o preso ser transferido mais rápido... ( ) Alguns empregadores consideram que oferecer uma vaga de emprego é um favor, eles nem precisam da mão de obra do preso, isso é injusto, porque nestes casos a proposta serve apenas para tirar o sentenciado do complexo e facilitar a transferência para o galpão”. Profissional 1
\end{abstract}

Esta denúncia pode justificar as informações prestadas pelo sentenciado 4, que relatou que não está recebendo salário há meses, mas mesmo assim acha o trabalho importante já que durante o dia ele pode se ausentar do presídio.

De acordo com as entrevistadas, o trabalho é um espaço de ressocialização através da inserção no mercado de trabalho, eleva a auto-estima do sujeito e o seu reconhecimento profissional "é como se fosse um perdão da sociedade ao preso" sic Profissional 2.

Embora o Trabalho Externo seja um benefício do cumprimento de pena, os direitos trabalhistas devem ser garantidos, mas as entrevistadas acreditam que estas atividades não se diferem do tipo de atividade que o sujeito encontraria fora do estabelecimento prisional, que é o mercado informal, o mercado sem proteção social:

“O trabalho externo é um benefício e por isso tem que ser regido pela LEP, mas nada impediria de ter certas vantagens como INSS, $13^{\circ}$ salário, tudo isso é justo. Mas diante do desemprego estrutural que estamos vivenciando, o sentenciado que tem um trabalho já está 
em vantagem, porque muitos que estão aqui fora e nunca praticaram nenhum crime, não estão trabalhando”. Profissional 2

“... de acordo com o termo de compromisso que o empregador assina o preso não deveria perder nenhum direito, porque lá diz que a carteira deve ser assinada, o INSS deve ser recolhido, que deve ter folha de ponto. Mas na prática com certeza isso não deve acontecer direitinho. Por outro lado, quando analisamos a vida deles, a falta de qualificação profissional e de escolaridade, concluímos que se eles não estivessem presos, com certeza estariam no mercado informal, onde não se tem direito mesmo. Então pelo termo de compromisso, pelo menos eles têm mais direito”. Profissional 1

A questão da formação profissional das pessoas entrevistadas e as atividades que as mesmas executam foram abordadas. Perguntamos se elas se sentem capacitadas para analisar as propostas de emprego, diante da formação profissional que possuem:

\footnotetext{
“Não me sinto capacitada. Não tenho experiência e nem conhecimento técnico e específico para verificar documentação das empresas, saber se o que é apresentado é verdadeiro ou falso... ( ) Curso de Direito Trabalhista seria importante” . Profissional 1 - Psicóloga com curso de aperfeiçoamento em Saúde Mental

"Sinto-me capacitada. Pela minha formação em Direito, Economia e até pelo Serviço Social... ( ) Economia deu para aprender muita coisa que eu aplico, mas até como Assistente Social me sinto capaz, não acho o trabalho tão difícil assim”. Profissional 2 - Assistente Social com especialização em Saúde Pública, Economista e no momento está cursando Direito.
}

A questão que permeia as atividades destes profissionais é se essa função é compatível com o papel da SEVEC e com a formação individual de cada profissional. A Seção tem a tarefa de acompanhar os sentenciados em regime semi-aberto, o que inclui também o trabalho. O que vem sendo realizado pela equipe é a triagem e a orientação, o acompanhamento não ocorre pela falta de recursos humanos.

A formação acadêmica de alguns facilita este trabalho e até o entendimento da posição profissional dentro das funções desempenhadas, como é o caso do Serviço Social que trabalha o indivíduo e as suas relações sociais, permeado de debates sobre direito e com uma visão crítica e contestadora da realidade.

Já a Psicologia, que lida com o indivíduo de forma focalizada, apresenta mais dificuldade de ver a sua formação acadêmica compatível com as atividades desenvolvidas, de triagem e orientação nos grupos. Por este motivo, a Psicóloga entrevistada demonstrou interesse e até necessidade de que o Tribunal de Justiça ofereça cursos específicos sobre Direito do Trabalho, Noções de Documentação e outros temas 
que melhorem a execução de suas atribuições, enquanto a Assistente Social declarou que não sente necessidade de cursos deste tipo.

Mesmo com essa diferença de abordagem e visões sobre o sujeito, o trabalho desses profissionais tem sido desempenhado de forma exemplar. A barreira da dificuldade de profissionais tem sido rompida pela articulação com outros profissionais, como policiais civis para realizarem as visitas às empresas, e a utilização do espaço das reuniões com os empregadores como um momento único, mas capaz de sanar as dúvidas e questionamentos sobre as regras e os benefícios. No término dos encontros, a equipe sempre se coloca à disposição dos empregadores no caso de eventualidades no decorrer do trabalho, fornecendo os números telefônicos da Seção e do presídio.

Podemos concluir que existe um tímido acompanhamento dos empregadores e sentenciados pelos profissionais da SEVEC, conseqüência direta da falta de recursos humanos, que impossibilita outros encontros com os responsáveis das empresas. $\mathrm{Na}$ Seção existem projetos específicos para que esse acompanhamento seja efetivado, mas a ausência de profissionais impossibilita a implementação. 


\section{Considerações Finais}

Na era do capitalismo o trabalho é a categoria central para as relações sociais, pois possibilita a interação com os demais sujeitos e a participação nos bens e serviços produzidos pela sociedade. Especificamente para os sentenciados do regime semi-aberto, é uma oportunidade de retorno à sociedade e diminuição do estigma de presidiário, sendo uma possibilidade de demonstrar regeneração e reabilitação.

O benefício do Trabalho Externo tem contribuído na inserção dos indivíduos ao mercado de trabalho através da parceria com empresas privadas, pois tem como fundamentação a importância social, econômica e política do trabalho. As atividades extra muros, proporcionam o afastamento do sentenciado do ambiente prisional, que de acordo com a pesquisa teórica e o discurso dos entrevistados, é um local que não oferece serviços de qualidade e nem a valorização do ser humano.

Além do distanciamento prisional, o trabalho estabelece novas relações sociais e pessoais ao preso. Desta forma, ele tem a possibilidade de construir novas perspectivas e projetos, longe da criminalidade.

Diante do estudo realizado, algumas proposições serão apresentadas na tentativa de melhorar este benefício.

\subsection{Criação de legislação específica sobre o Trabalho Externo}

As legislações que regulam o benefício do Trabalho Externo são a Lei de Execução Penal e o Código Penal. Não existe nenhuma portaria, decreto ou lei específica que delimite os critérios para a obtenção do benefício de trabalhar durante o dia em empresas privadas.

Não existem critérios claros e objetivos de que tipos de empresas podem se candidatar a empregar um sentenciado, quais as funções que o preso em regime semiaberto pode realizar e como a fiscalização operaria nestes casos. Salários, direitos trabalhistas e as responsabilidades do empregador também estão mais no campo das subjetividades do que do positivismo. 
A definição de critérios que serviram igualmente para todos os sentenciados que pleiteiam o benefício, evitará que a subjetividade de profissionais interfira na concessão do Trabalho Externo. A regulamentação deve ser resultado da articulação de todas as esferas envolvidas: profissionais da SEVEC, Juizes e Equipe de fiscalização do presídio.

\subsection{Acompanhamento dos sentenciados e trabalhadores pela equipe da}

\section{SEVEC}

Dentro da legislação que servirá para regulamentar o benefício de forma mais específica, o acompanhamento aos presos e aos empregadores deve ser considerado como um dos pilares. Os profissionais da SEVEC são os mais indicados para realizar esta atividade, porque eles já são responsáveis pelo contato com os familiares nos casos de Saídas Temporárias e pela triagem dos empregadores.

De uma forma tímida esta atividade já é realizada. Precisa-se ampliar este contato com os responsáveis pela empresa, que ocorre uma única vez no momento da explicação das regras do beneficio, para um acompanhamento sistemático e contínuo. A SEVEC deve ser vista como uma seção onde o empregador e o sentenciado podem recorrer em casos de dificuldade no campo de trabalho.

A grande dificuldade para a implementação deste acompanhamento é a escassez de profissionais. Tendo em vista essa peculiaridade sugerimos a utilização de questionários básicos onde empregadores e presos responderão sobre como as atividades estão sendo desenvolvidas. Nos casos onde dificuldades forem detectadas como uso de drogas, porte de arma, não cumprimento de horários e regras, salários atrasados e outras irregularidades, a equipe de SEVEC pode realizar uma visita ao local ou marcar uma reunião entre as parte para tentar solucionar o problema.

Os questionários podem ser enviados pela Internet para o e-mail do Tribunal de Justiça do profissional responsável. Desta forma, ainda existirá um vínculo com os responsáveis pela proposta e com o sentenciado, mesmo com a saída do processo da SEVEC.

Neste processo de acompanhamento, a atuação dos Assistentes Sociais é imprescindível, pois ele é capacitado para atuar na intervenção individual, na orientação quanto aos direitos e no acompanhamento de determinados segmentos. 
A Lei 8.662/93 que trata das disposições sobre a profissão do Assistente Social, traz em seu artigo $3^{\circ}$ as competências deste profissional. O inciso 5 diz que é sua atribuição “orientar indivíduos e grupos de diferentes segmentos sociais no sentido de identificar recursos e de fazer uso dos mesmos no atendimento e na defesa de seus direitos;" e o inciso 9 "prestar assessoria e apoio aos movimentos sociais em matéria relacionada às políticas sociais, no exercício e na defesa dos direitos civis, políticos e sociais da coletividade”.

\subsection{Incentivos fiscais para as empresas}

A responsabilidade pela inserção do preso egresso ao mercado de trabalho é do Estado. Por isso, quando a sociedade civil assume este papel ele deve receber algum tipo de incentivo, que não é a perda dos direitos trabalhistas.

Já existem programas similares onde as empresas recebem incentivos reais para empregar um determinado segmento da sociedade. O programa Primeiro Emprego é um bom exemplo de parceria entre Governo e Sociedade Civil. O programa tem o objetivo de gerar emprego para jovens entre 16 e 24 anos. Para cada vaga gerada a empresa recebe um salário mínimo ou o piso da categoria limitado ao teto de dois salários mínimos durante seis meses ou podendo optar em receber de 3 a 6 parcelas em caso de atividade sazonal. (PROGRAMA PRIMEIRO EMPREGO, 2004).

Baseados na existência de programas de oferecer subvenções econômicas às empresas que tentam diminuir a inexperiência dos jovens é que entendemos que os mesmos critérios e vantagens podem ser utilizados para estimular empresas que resolvem oferecer proposta de empregados aos sentenciados do regime semi-aberto.

\subsection{Ampliação do número de vagas no presídio de regime semi-aberto e} aumento da fiscalização às empresas

Como os presos que já possuem vaga de trabalho têm prioridade para serem transferidos de presídio, algumas famílias e advogados se aproveitam desta vantagem para oferecer propostas inexistentes ou irregulares. A forma mais eficaz de solucionar esta questão é primeiramente aumentar o número de vagas do regime semi-aberto. 
O CPP pretende inaugurar até o mês de julho de 2007 um novo galpão com vaga para mais 400 homens, localizado ao lado do atual Centro de Progressão Penitenciário, no Setor de Indústrias e Abastecimento.

Quando estes presos saem para trabalhar e durante as suas atividades são visitados por policiais civis, eles se sentem coagidos de não cumprir os horários estabelecidos e de utilizar o período de trabalho para praticarem novos delitos. Porque sabem que serão penalizados.

Por isso a tarefa de fiscalizar é fundamental para o bom êxito do benéfico, bem como as garantias que as propostas apresentadas serão idôneas, porque passarão por verificação contínua.

\subsection{Trabalho associado à Educação e outras políticas sociais}

O trabalho prisional é fundamental para a reinserção do indivíduo na sociedade, pois desta forma o indivíduo estará desenvolvendo suas habilidades naturais, mantendo relações com outras pessoas, produzindo, diminuindo a ociosidade do estabelecimento prisional e tendo necessidade de novos conhecimentos e técnicas.

Mas somente o trabalho não pode ser responsável por toda a gama de mudanças psicossociais que a prisão e a sociedade exigem do interno. Para melhorar a eficácia deste benefício, ele deve ser trabalhado de forma conjunta com outras políticas, como educação, saúde, alimentação e direitos humanos.

Sem educação o trabalho se torna apenas um período de diminuir o ócio. Pois a qualificação da mão de obra do trabalhador continua a mesma, sem planos e projetos para o futuro e sem perspectiva de melhoria de vida através do trabalho.

As saídas para o trabalho não podem ser uma "fuga" da precarização do sistema carcerário, da falta de dignidade do ser humano, para que os presos não aceitem qualquer tipo de trabalho, somente para sair do presídio, abrindo mão de direitos, salário e facilitando a exploração da sua força de trabalho. 


\section{Bibliografia}

ALMEIDA, Érika. T. V. de. Crítica da metamorfose do conceito de sociedade civil em "terceiro setor" In: Serviço Social e Sociedade n ${ }^{\circ}$ 8, ano XXV, novembro de 2004. São Paulo: Cortez, 2004.

ANTUNES Ricardo. Adeus ao Trabalho. Ensaios sobre as metamorfoses e a centralidade no mundo do trabalho. 5. ed. São Paulo: Cortez, 1998.

BECCARIA, Cesare. Dos Delitos e das Penas. São Paulo: Ed. Martin Clarim, 2002.

BEHRING, Elaine; BOSCHETTI, Ivanete. Política Social: fundamentos e história. São Paulo: Cortez, 2006.

BOSCHETTI, Ivanete. Assistência Social no Brasil: um direito entre originalidade e conservadorismo. Brasília: GESST/ SER/ UnB, 2003.

CAMARGO, Maria Soares de. A prisão, In: Revista Serviço Social e Sociedade $n^{\circ} 33$, ano XI, Cortez, 1990.

CARDOSO, Maria Cristina Vidal. A cidadania no contexto da Lei de Execução Penal: O (des)caminho da inclusão social do apenado no Sistema Penitenciário do Distrito Federal. Tese de mestrado para obtenção do Título: Mestre em Política Social do Departamento de Serviço Social. Brasília, 2006.

COUTINHO,C.N. Gramsci: um estudo sobre o pensamento político. Rio de Janeiro: Civilização Brasiliense, 1999.

: Notas sobre a Cidadania e Modernidade. In: Revista Praia

Vermelha: estudos da Política e Teoria Social, vol I, nº 01, PPGESS/ UFRJ, 1997.

DEPEN,B Pesquisa do ano de 2005 do Departamento Penitenciário Nacional. Brasília: Departamento Penitenciário Nacional, 2005.

FILHO, Roberto Lyra. O que é direito? São Paulo: Editora Brasiliense, 1982.

FOUCAULT, Michel. Vigiar e Punir: nascimento da prisão. Petrópolis: Editora Vozes, 1987.

FUNAP. Pesquisa do ano de 2005 da Fundação Nacional de Amparo ao Preso. Brasília: Fundação Nacional de Amparo ao Preso, 2005.

INFOPEN, Sistema Penitenciário - Distrito Federal dezembro de 2006. Brasília, 2007.

Acesso em: www.mj.gov.br/depen/sistema/2006/dezembro Em: 21 de março de 2007, às 20.25

KUEHNE, Maurício. Lei de Execução Penal Anotada. Curitiba: Juruá, 2000. 
MARX, Karl. O capital. São Paulo: Brasiliense, 1988.

MUAKAD, Irene Batista. Prisão Albergue. São Paulo: Cortez, 1984.

PEREIRA, Potyara. Estado, regulação social e controle democrático. In: Bravo, $\mathrm{M}^{\circ}$ Inês, PEREIRA, socialista. Lisboa: Edições 70, 1976.

PIERSON, Christopher. Beyond the Welfare State? The new political economy of welfare. 2end ed. Cambridge. 1998.

PRIMEIRO EMPREGO, em: http://www.primeiroemprego.rs.gov.br/welc.html Acesso em: 20 de maio de 2007.

RADAR SOCIAL, Radar Social.

Acesso em: www.ipea.gov.br/destaques/livroradar/trabalho

Em: 14 de maio de 2007, às 22.05.

SANTOS, Vera Lúcia Silano Domingues. O papel desempenhado pelo trabalho do (a) preso(a) no seu processo de reinserção social. Dissertação de Pós - Graduação para obtenção do título Especialista em Modalidades e Tratamento Prisional, Curitiba., 2003.

SEÇÃO PSICOSSOCIAL DA VARA DE EXECUÇÕES CRIMINAIS, Plano de ação de 2001/2002: Vara de Execuções Criminais, Brasília: Tribunal de Justiça do Distrito Federal e Territórios, 2001.

SEBRAE DF. Em : www.df.sebrae.com.br/_mostrapagina Acesso em : 15 de maio de 2007.

SILVA, José de Ribamar de. Prisão: Ressocializar para não reincidir. Dissertação de Pós - Graduação par obtenção do título Especialista em Modalidades e Tratamento Prisional, Curitiba., 2003.

TELLES, V. S. Sociedade civil e a construção de espaços públicos. In: Dagnino, Eveline (org). Anos 90: Políticas e Sociedade no Brasil. São Paulo: Brasiliense, 1994.

WAUTERS, Edna. A Reinserção Social pelo Trabalho Dissertação de Pós Graduação par obtenção do título Especialista em Modalidades e Tratamento Prisional, Curitiba., 2003. 


\section{Anexo 1}

\section{- Legislação sobre o Trabalho Externo}

O trabalho externo em empresas privadas é pautado na Lei de Execução Penal em seus artigos 28, 29, 36 e 37:

Art. 28. O trabalho do condenado, como dever social e condição de dignidade humana, terá a finalidade educativa e produtiva.

$\S 1^{\circ}$ Aplicam-se à organização e aos métodos de trabalho as precauções relativas à segurança e à higiene.

$\S 2^{\circ} \mathrm{O}$ trabalho do preso não está sujeito ao regime da Consolidação das Leis do Trabalho

Art.29. O trabalho do preso deverá ser remunerado, mediante prévia tabela, não podendo ser inferior a três quartos do salário mínimo.

$\S 1^{\circ}$ O produto da remuneração pelo trabalho deverá atender:

a) a indenização dos danos causados pelo crime, desde que determinados judicialmente e não reparados por outros meios;

b) a assistência à família;

c) a pequenas despesas pessoais

d) ao ressarcimento ao Estado das despesas realizadas com a manutenção do condenado, em proporção a ser fixada e sem prejuízo da destinação prevista nas letras anteriores

Art. 36. O trabalho externo será admissível para os presos em regime fechado somente em serviços ou obras públicas realizadas por órgãos da administração direta ou indireta, ou entidades privadas, desde que tomadas as cautelas contra fuga e em favor da disciplina.

$\S 1^{\circ}$ O limite máximo do número de presos será de dez por cento do total de empregados na obra.

$\S 2^{\circ}$ Caberá ao órgão da administração, à entidade ou à empresa empreiteira a remuneração desse trabalho.

$\S 3^{\circ}$ A prestação de trabalho a entidade privada depende do consentimento expresso do preso.

Art. 37. A prestação de trabalho externo, a ser autorizada pela direção do estabelecimento, dependerá de aptidão, disciplina e responsabilidade, além do cumprimento mínimo de um 1/6 da pena. 
Anexo 2

Motivos detalhados de desligamento de sentenciados 2001-2004

\begin{tabular}{|c|c|}
\hline Motivos Positivos (SUBTOTAL) & 241 \\
\hline Trabalhar na cantina do CPP & 1 \\
\hline Transferiu processo para Planaltina - GO & 1 \\
\hline Recebeu indulto pleno & 7 \\
\hline Obteve trabalho particular & 56 \\
\hline A pedido do mesmo & 65 \\
\hline Término de pena & 111 \\
\hline Comportamentos Inadequados (SUBTOTAL) & 954 \\
\hline Não puderam assumir o posto de trabalho & 31 \\
\hline Apresentou problemas & 1 \\
\hline Atrasos injustificados & 1 \\
\hline Briga com funcionário & 1 \\
\hline Discussão com servidor & 1 \\
\hline Embriaguez & 1 \\
\hline Estar de castigo no CPP & 1 \\
\hline Excesso de atestado médico & 1 \\
\hline Furto em residência & 1 \\
\hline Furto de CPU & 1 \\
\hline Internado no HRC & 1 \\
\hline Não cumpre as determinações da chefia & 1 \\
\hline Posse de um faca & 1 \\
\hline Preso em flagrante & 1 \\
\hline Estelionato & 1 \\
\hline Ser causador de problemas & 1 \\
\hline Suspeita de furto & 1 \\
\hline Trabalho pesado e problema de saúde & 1 \\
\hline Não querer exercer a função a ele designada & 2 \\
\hline Autuado em flagrante & 2 \\
\hline
\end{tabular}




\begin{tabular}{|c|c|}
\hline Detido em Delegacia & 2 \\
\hline \multicolumn{2}{|l|}{ Comportamentos Inadequados (Continuação) } \\
\hline Discussão com outro sentenciado & 2 \\
\hline Indisciplina & 2 \\
\hline Não atende as necessidades do convênio & 2 \\
\hline Não tem interesse em permanecer no trabalho & 2 \\
\hline Recuperação pós cirúrgica (baleado) & 2 \\
\hline Suspensão do trabalho externo & 2 \\
\hline Uso de bebida alcoólica & 2 \\
\hline Uso de entorpecentes no local de trabalho & 2 \\
\hline Excesso de faltas & 3 \\
\hline Fraco desempenho no trabalho & 3 \\
\hline Não cumpre seu horário & 3 \\
\hline Comportamento Inadequado & 4 \\
\hline Considerado improdutivo & 4 \\
\hline Falta de compromisso & 4 \\
\hline Inquérito Disciplinar (CPP) & 4 \\
\hline Constantes faltas e atrasos & 5 \\
\hline Convênio deseja renovar o quadro & 5 \\
\hline Desentendimento entre conveniados & 5 \\
\hline Falta de responsabilidade com o trabalho & 5 \\
\hline Não corresponde às expectativas do convênio & 5 \\
\hline Não cumpre suas tarefas & 5 \\
\hline Ausentava-se do serviço sem justificativa & 7 \\
\hline Término do convênio & 7 \\
\hline Não comparecimento ao trabalho & 8 \\
\hline Falecimento & 9 \\
\hline Não se adaptou ao trabalho & 10 \\
\hline Não adaptação às atividades atribuídas & 11 \\
\hline Condicional/Domiciliar convênio sem VT & 14 \\
\hline Convênio não comunicou o motivo & 73 \\
\hline Comportamentos Inadequados (Continuação) & \\
\hline
\end{tabular}




\begin{tabular}{|c|c|}
\hline Abandono ao trabalho & 26 \\
\hline Contenção de Despesas do convênio & 40 \\
\hline A pedido do convênio & 52 \\
\hline Foragido & 122 \\
\hline Recolhido & 129 \\
\hline Não cumprimento às normas do convênio & 137 \\
\hline Faltas injustificadas & 184 \\
\hline TOTAL DE DESLIGAMENTOS & 1195 \\
\hline
\end{tabular}




\section{Anexo 3}

\section{Termo de Consentimento Livre e Esclarecido}

$\mathrm{Eu}$, declaro que fui informado

(a) e compreendi que a pesquisa sobre Trabalho Externo dos presos em regime semiaberto, em empresas privadas do Distrito Federal tem como objetivo conhecer como este trabalho vem sendo desempenhado, a partir das metamorfoses do mundo do trabalho. Sendo assim, decidi voluntariamente participar dessa pesquisa sob responsabilidade da pesquisadora Fabiana Jardim Sena.

Gostaria de declarar também ter sido informada que a minha participação não implicará em qualquer tipo de remuneração e o sigilo em torno de minha identidade será assegurado em todas as etapas da pesquisa. Terei ainda o direito de desistir de participar desta pesquisa a qualquer momento e diante de tal decisão não haverá nenhum ônus para a minha pessoa.

As informações obtidas através dessa pesquisa serão confidenciais e asseguramos o sigilo sobre sua participação. Os dados não serão divulgados de forma a possibilitar sua identificação.

O termo foi assinado por mim e pela pesquisadora.

Brasília, de de 2007.

Assinatura da pessoa entrevistada

Assinatura da pesquisadora 


\section{Anexo 4}

\section{Modelo de entrevista com sentenciado, empregador e profissionais}

Roteiro de entrevista: Sentenciado

Identificação:

Idade:

Grau de escolaridade:

Trabalho anterior:

Especialização de mão de obra (cursos):

Estado civil:

Quantidade de filhos:

Quanto à empresa

- Qual o ramo da empresa

- Salário

- Benefícios recebidos

- Horário de trabalho

- Quantidade de funcionários

- Quantidade de funcionários na condição de sentenciado em regime semi-aberto

- Já houve algum tipo de discriminação ou preconceito pela condição de preso? Quais?

Quanto à reinserção

- A vaga de emprego ajudou na reinserção social?

- Por que o empresário ofereceu esta vaga?

- O que poderia ser feito para aumentar as vagas de trabalho em empresas privadas?

Quanto aos direitos

- Quais são os diretos trabalhistas de um trabalhador?

- O sentenciado em regime semi-aberto usufrui destes direitos? Por quê?

- O seu salário é o mesmo dos demais funcionários que desempenham as mesmas atividades?

- A jornada de trabalho é a mesma dos demais funcionários?

Observações adicionais: 


\section{Anexo 5}

\section{Roteiro de entrevista: Responsável legal pela empresa}

Quanto à empresa

- Qual o porte da instituição

- Ramo de atuação

- Quantidade de funcionários

- Quantidade de funcionário na condição de sentenciado em regime semi-aberto

Quanto à natureza da proposta

- O que levou o empregador a oferecer a proposta de emprego

- Grau de parentesco com o sentenciado

Quanto aos direitos

- O que o empregador entende por direitos trabalhistas

- A empresa garante direitos como décimo-terceiro salário, FGTS, Férias Remuneradas, Licença Paternidade, Horas extras e outros?

- Caso o sentenciado possua qualificação profissional específica ou curso superior ele tem condições de ascensão dentro da empresa?

- O salário pago ao sentenciado é o mesmo dos demais funcionários que desempenham a mesma atividade?

- O sentenciado já sofreu algum tipo de discriminação ou preconceito dentro da empresa?

Quanto à responsabilidade social

- Qual a importância de se empregar um sentenciado neste momento de reinserção social?

- Quais são os incentivos fiscais e sociais que a empresa recebe ao oferecer este trabalho ao sentenciado?

- Se existissem outros incentivos fiscais, o empresário empregaria mais sentenciados?

- O artigo infringido teve alguma influência em ofertar o emprego? Qual o crime cometido? 


\section{Anexo 6}

Roteiro de entrevista: Profissionais responsáveis pela análise das propostas de emprego

Quanto à natureza da proposta

- O que o profissional considera mais relevante no momento que um empregador oferece uma proposta de trabalho

- Qual a sua opinião sobre os tipos de trabalho oferecido

Quanto à atuação profissional

- Quais são as atividades desenvolvidas com relação às propostas de trabalho ofertadas?

- Qual a importância do trabalho na reinserção do preso?

- O fato do trabalho do sentenciado ser regido pela LEP e não pela CLT implica em alguma perda de direito?

- O que poderia ser alterado para melhor o benefício do Trabalho Externo?

Observações Adicionais: 


\section{PODER JUDICIÁRIO}

TRIBUNAL DE JUSTIÇA DO DISTRITO FEDERAL E TERRITÓRIOS

VARA DE EXECUÇÕES CRIMINAIS DO DISTRITO FEDERAL - VEC

\section{TERMO DE COMPROMISSO DO EMPREGADOR}

Declaro perante o Juízo da Vara de Execuções Criminais do Distrito Federal, dispor de emprego para o sentenciado abaixo nominado, observando o seguinte:

\section{Sentenciado:}

Empresa:

CNPJ:

Nome Fantasia:

Endereço:

CEP: Telefone:

Função do sentenciado

Dias e horários de trabalho

\section{Salário total:}

Remuneração adicional:

Atividades desenvolvidas:

Observações quanto ao trabalho:

Responsável legal pela empresa:

CPF:

E-mail :

OBSERVAÇÕES: 


\section{NORMAS PARA TRABALHO EXTERNO}

1. O empregador deverá comunicar imediatamente ao Juiz de Execuções Criminais quaisquer alterações no local e no contrato de trabalho;

2. O empregador deverá informar ao Juiz de Execuções Criminais as ausências do sentenciado e afastamentos justificados ou não, inclusive para tratamento de saúde;

3. O sentenciado deverá permanecer na empresa pelo prazo mínimo de 90 dias a título de experiência, salvo situações devidamente justificadas;

4. De acordo com a Lei de Execução Penal (LEP), o trabalho do sentenciado deverá ser remunerado;

5. Fica o empregador intimado de que, nos termos do decreto 4729/03, todo sentenciado agraciado com o trabalho interno ou externo, passa a ser segurado obrigatório da Previdência Social, sujeitando-se à legislação previdenciária vigente;

6. Mensalmente, o empregador deverá encaminhar ao CPP (Centro de Progressão Penitenciária) cópia da folha de ponto ou outro comprovante de freqüência ao trabalho;

7. No prazo de 15 (quinze) dias, após o início do trabalho, o empregador deverá encaminhar ao CPP cópia da carteira de trabalho ou contrato de trabalho;

8. Sempre que solicitado por qualquer autoridade encarregada de fiscalizar a execução penal, o empregador deverá prestar informações sobre o comportamento e o desempenho do sentenciado no trabalho e apresentar folha de ponto ou outro comprovante de freqüência.

Feita a leitura das condições estabelecidas no presente termo, declarou o empregador conhecê-las e aceitá-las, tal como apresentadas.

Ciente sob as penas legais comprometeu-se a seguir fielmente as normas prescritas por esse Juízo para o trabalho externo do sentenciado.

Brasília, de de 2007.

\section{ASSINATURA}

TRIBUNAL DE JUSTIÇA DO DF - VEC SRTVS ED. INTERCON $4^{\circ}$ ANDAR

Seção Psicossocial da VEC: 3312-1531 / 3312-1532 Cartório da VEC : 3312-1515 / 3312-1524

Centro de Progressão Penitenciária (CPP) : 3901-6231 / 3901-6233 / 3901- 6234

Penitenciária Feminina do Distrito Federal (PFDF): 3901-7190 / 3901-6244 